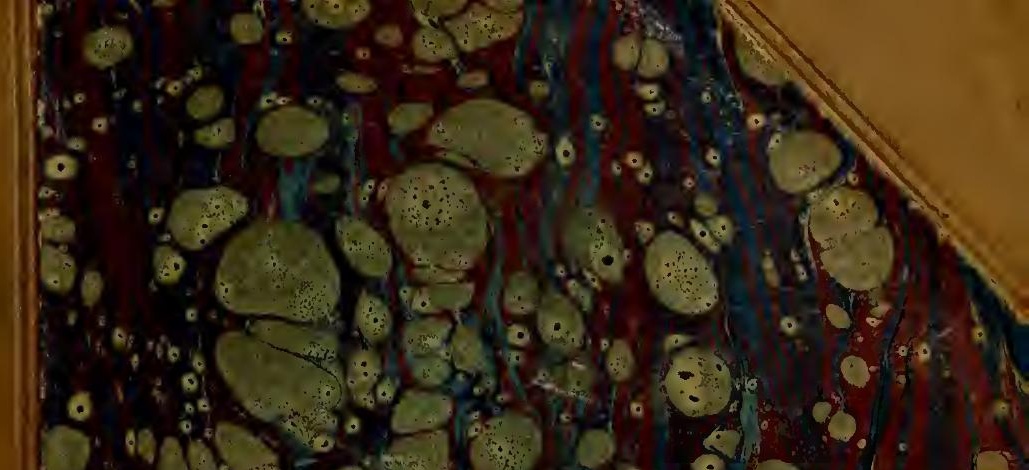

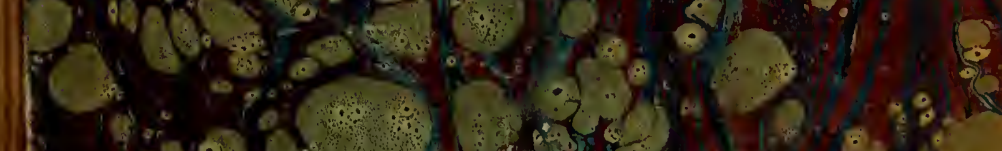

36.

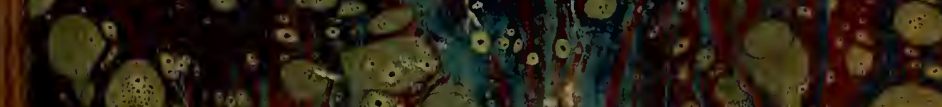

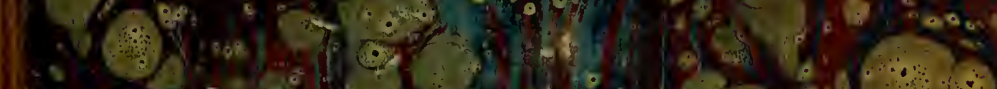

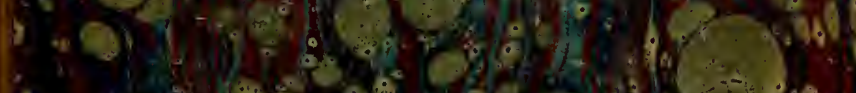

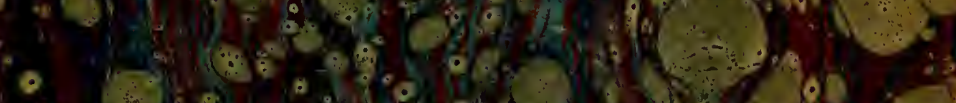

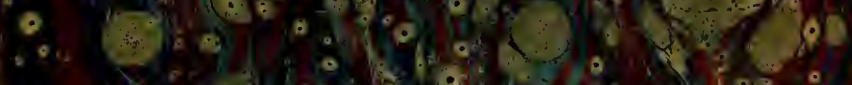

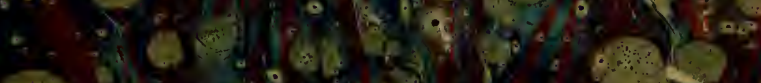

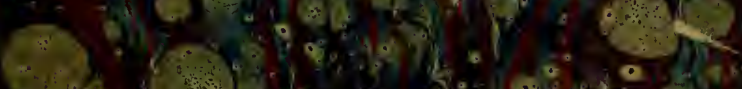

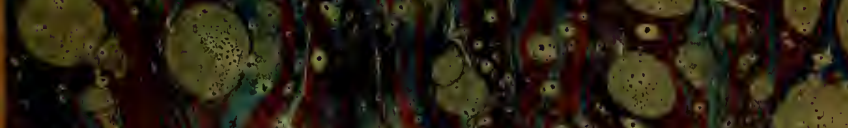

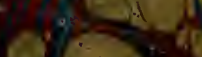

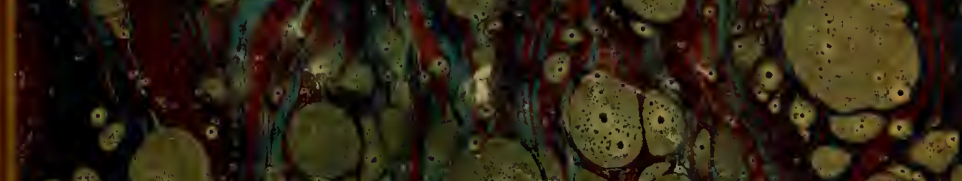

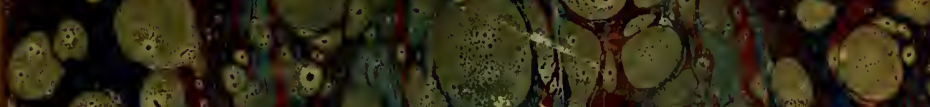

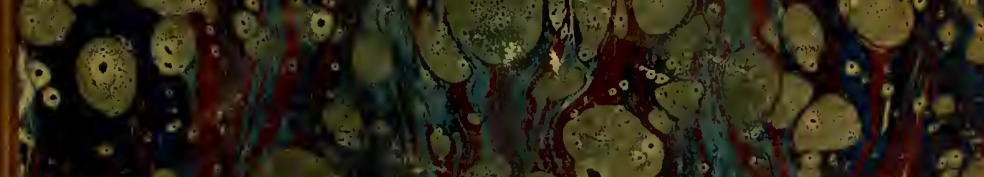
(1)

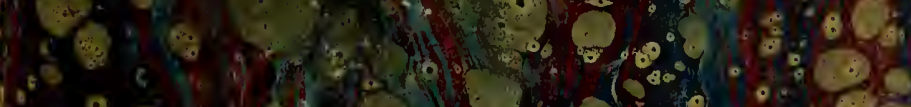

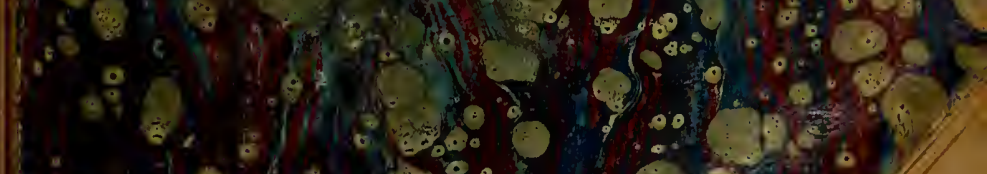

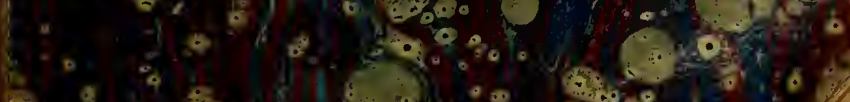

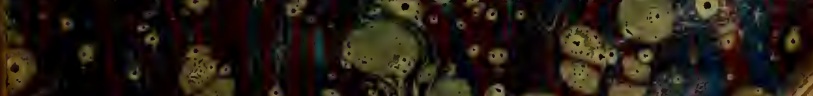
4 a 


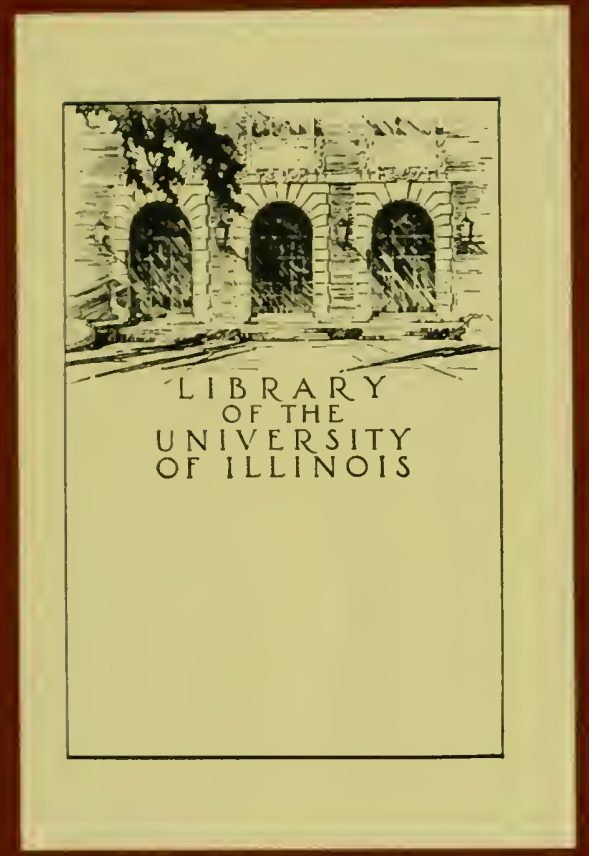






\section{THE AGRICULTURAL DEPRESSION}

AND

\section{THE SUFFERINGS OF THE CLERGY.}

BY

R. E. PR 0 TH ER 0 .

FFLLOW OP ALL SOULS' COLLEGE, OXFORD.

REPRINTED FROM "THE GUARDIAN."

LONDON :

"GUARDIAN" OFFICE, 5, BURLEIGH STREET, STRAND. 1887. 



\section{CONTENTS.}

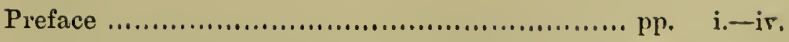

Letter I. The general effect upon clerical incomes of agricultural depression ............ pp. $1-7$

Letter II. The effect upon the titheowner $\ldots . .$. pp. 8-18

Letter III. The effect upon the glebeowner ..... pp. 19-31

Letter IV. The relief of the titheorner ........ pp. 32-41

Letter V. The relief of the glebeowner .......... pp. 42-52 


\section{P R E F A E E.}

一出-

At the close of last year I accepted an offer from the Editor of the Guardian to inquire into the effects on clerical incomes of the prolonged agricultural depression. The results of my inquiry are contained in the following five letters.

These so-called letters are really articles. The abstract form and want of local colour are due, partly to the difficulty of investigating the private liabilities of men in the rank of the rural clergy, partly to the necessity, when information of this character was obtained, of aroiding the identification of the informant. The ground on which the pledge of secrecy was in one case exacted was significant enough in its latent meaning- "If names were divulged it might injure my credit."

It is not suggested that all clergymen have in an equal degree suffered from the agricultural depression. The inquiry was mainly confined to the counties of Northampton, Huntingdon, and Essex, and the borders of Nottingham, Leicester, Lincoln, North Warwick, and Buckingham, the districts in which the prolonged depression was known to have produced its most disastrous results.

Even in these counties only general statements are possible, owing to the varying circumstances of different benefices and different localities.

Clergymen who are titheowners only, in counties unaffected by anti-tithe agitation, have, at the worst, passed from the enjoyment of ease to the practice of economy; they have lost their margin of comfort.

Clergymen who are titheowners in counties upon which the anti-tithe agitation has taken a firm hold have been compelled to make remissions varying from 10 to 25 per cent. upon the existing value (90 per cent.) of the tithe rent-charge. Their income has already dropped from the 112 of twelve years since : it is also reduced by arrears. But in case they refuse to make abatements they lose their incomes altogether.

Clergymen whose income is derived partly from tithes and partly from glebe, and whose benefices are situated in a county into which the anti-tithe agitation has spread, are still worse off. They sustain a double loss. Their tithe is reduced; 
or refused, and they are obliged to take whaterer rent they can get from their glebes.

But the clergymen who have suffered most heavily are those whose income is exclusively derived from glebe. If they let their land, the rent falls 33 to 50 per cent. Those who hare been compelled from inability to find tenants to farm their own land have lost their rent and their private capital as well. I only encountered a single instance in which glebeowners farming their own land would not have been, but for private means or friendly assistance, literally and without metaphor, starving.

Upon the results of my inquiry two general questions seen to arise-(1) what immediate measures of relief are possible? (2) What is to be the uItimate fate of tithe rent-charges and of glebe-lands?

Speaking generally on a subject which is treated in detail in my letters, I have come to these conclusions :-

1. As to Tithes.-As a temporary relief the payment of tithes must be undertaken by the landlords; but the only final solution of the tithe difficulty is, I believe, their compulsory redemption,* a course which I venture strongly to advocate.

2. As to Glebes.-A gradual sale, wherever reasonable offers can be obtained, is advisable. An immediate sale, forced on by panic, will glut the market with land; the proceeds of such a sale at present prices would realise little more than the auctioneer's charges. Meanwhile the legal impediments by which glebeowners are hampered in the derelopment of their land can be, and ought to be, at once removed. No legislative change will remove the personal and professional difficulties under which clerical landlords must inevitably labour. But they may be modified. For a discussion of this part of the subject the reader is reforred to the third and fifth letters.

The difficulty which is experienced in filling up vacant glebe livings may be partially and temporarily met by further amendments of the Pluralities Acts giving increased powers to Bishops to throw livings together.

For the immediate distress of glebeowners the following appears to me the most efficacious form of relief. I do not put the scheme forward as one of those many devices for

- In describing Mr. Ryde's scheme (Fourth Letter) I only advocate its principle-namely, compulsory redemption by co-operation between the landlords and the Government. 
raising money which threaten to turn the year of Jubilee into a year of tribulation.

Glebeowners have sunk a large amount of private capital in the improvement of their lands, for the repayment of which they have no security and on which they receive no interest. Again they have charged their glebes with heavy loans raised for the same purpose from Land Improvement Companies. If the land is unlet the premiums fall into arrear, and the companies or their assignees are compelled to foreclose. By this process two livings have been already disendowed, and the same fate hangs suspended by a hair over sereral midland county benefices. All the possible increase on the present value of the land is for ever lost to the Church. Again, clergymen in more prosperous times incurred charges to Queen Anne's Bounty for building houses; these charges now hang like millstones round their necks. Again, pensions were granted to retiring incumbents under the Incumbents' Resignation Act, which were calculated upon the old value of the living, but which have now become wholly disproportionate. The result of the loss of private capital and of the incidence of these annual fixed charges is that, as their incomes fall, clergymen are compelled to sell, pledge, or drop their life insurances, and thus to leare their families wholly unprovided for.

In the foregoing paragraph are summed up some of the most disastrous results to the Church and the clergy of the agricultural depression. Is there any remedy? I should propose that a fund be raised for the purpose of redeeming the charges held by Land Improrement Companies and, in cases where the charge was reasonably incurred, by Queen Anne's Bounty, and extending the period over which is to be spread the repayment of principal and interest. The relief to individuals would be great and immediate; and the Church would escape the danger of being disendorred through foreclosure of mortgages. The income or, if a sufficient sum were raised, the surplus might be devoted towards the following purposes:-1. In case of the leath or resiguation of glebeowners, who have sunk private capital on their glebes in structural improvements or improrements of so permanent a nature as drainage, compensation should be offered to them, or their representatives, and a cliarge be taken upon the benefice for the repayment of the amount, principal and interest. 2. An amendment of the Incumbents' Resignation Act scems imminent; a sliding scale 
and minimum income for the real incumbent will be fixed. But no amending Act can be retrospective in its operation. In the case of pensions settled before the impending amendment, tho real incumbent might be paid the difference between the sun which he pays for the fixed pension and that which he would pay under the sliding scale. 3. The abandonment or the mortgage of life insurances is the most lamentable result of agricultural depression. A clergyman becomes unable from diminution of professional income to keep up his insurances; the society might on the security of his policy give that temporary aid which often is all that is required; or, if from the same cause he was forced to drop the policy, and the case were one of genuine distress, the society might deal more leniently with the vendor than any public company which has to consider the interests of its shareholders. I need not indicate the many forms such leniency might assume.

What sum of money would be required for this task? In the diocese of Peterborough alone upwards of 50,0002 . of private capital has been sunk in the improvement of glebe, and an equal amount has been raised for the same purposes by charges from Land Improvement Companies. Of this latter sum a considerable portion has been now paid off. It is probable that $150,000 l$. would go a long way towards redeeming all the land improvement charges throughout the country. It is to be remembered that great mineral wealth in the shape of ironstone is to be found under the glebes in Northants; in some instances this source of wealth is untouched owing to a dead-lock between the Ecclesiastical Commissioners and the patrons. If legislation facilitated the development of the minerals under glebe-lands throughout the county, a sum could be raised which, supplemented by private subscriptions, and applied as I have indicated, would confer an inestimable boon on the distressed clergy. The work of redeeming land charges might be effected piecemeal : it might be commenced even with $1,000 t$. If once the society were launched it would float of itself, and, as a Clerical Land Improvement Company, would prove an invaluable means of removing the stigma of bad farming which not unfairly lies on glebe-lands. With its aid glebes would become more lettable and more salable.
Jamuary 28, 1887.
R. E. Prothero. 


\section{I.-THE GENERAL EFFECT UPON CLERICAL INCONES OF AGRICULTURAL DEPRESSION.}

At the present day it is impossible to regard the lot of landlords who depend for their incomes solely on their rents as altogether enviable. Their social position has ceased to be exceptionally dignified or secare. Among the many illusions which the experience of the nineteenth century has removed, none lias been more rudely dispelled than this nnsubstantial dream of the felicity of the landlords. The idyllic squire has taken his place with the Arcadian shepherd as the most unreal of poetic fictions. But the public mind is unsatisfied without an ideal of pastoral happiness. In the absence of other competitors the country clergyman has been selected to play the part. The delusion gathers strength, fostered by the misrepresentations of agitators and encouraged by the silence of the clergy them. selves, that the parsons daring the past ten years havo enjoyed a comfortable shelter on the lee-side of the storm. It is admitted that lay landlords have lost at least a third of their rents, and tenant farmers a large portion, if not the whole, of their working capital ; but it is assumed that incumbents continue to receive their revenues from land, little, if at all, diminished in amount by agricultural distress. Incumbents are held up to pablic condemnation as extortioners who squeeze blood out of stones, as sleeping partners in a losing business, as drones who paralyse the energies of farmers, and cripple the resources of landlords, by drawing from the land, without risk or ansiety, comfortable fixed incomes which can only be paid out of the capital of working agricalturists.

It is at least an open question whether the connection of the clcrgy with the land is desirable in the best interests both of the Church and of the nation. Lifo tenancies and fixed money payments charged apon the land are necessarily incnmbrances to agricultare. On the advantages or inconveniences of rentcharges or glebe lands I shall have something to say hereafter; nor is it my present parpose to discuss the amount of truth contained in the complaint against clerical landlords. The point upon which I am now insisting is that the connection of the clergy with the land has created a widespread discontent, and that this discontent is in a large measure due to the impression that the clergy have neither borne their fair share of agricultural distress, nor done their utmost to raise the burdens 
under which landed interests have collapsed. This feeling is fed from many other sources, snch as the covetousness which the possession of land always engenders in the landless, or the conviction that it is impossible for the clergy to be good landlords. But leaving out of sight all other sonrces of discontent except the belief in the immunity and the apathy of the clergy, it is manifest that judgment cannot safely be permitted to issue against the parsons by default, that it is not only just but prudent to lay the true facts before the pablic, and that both the sufferings of the clergy and the peculiar conditions by which, as agriculturists, they are hampered, are too little known or too generally ignored. It is with this object that the present inquiry has been instituted. The investigation has been principally confined to the dioceses of Peterborough, Ely, St. Albans, Lincoln, and Oxford; but the area has been considerably extended by the information of well-known and experienced land agents, whose wide basiness connections have made them acquainted with other parts of the country. The result of the inquiry shows that, in the first place, so far from enjoying any immnnity from agricultural loss, the clergy have suffered as acntely as any other class; and that, in the second place, their great and self-denying efforts to meet the agricultural crisis have been thwarted by impediments from which lay landlords and tenants have been long relieved. They have a claim on sympathy; they have also a claim for redress.

The prodence of raising the question can hardly be challenged. Agricultural distress has reached such a point of depression that it is no longer wise to conceal the sufferings of the clergy. If the tnrning-point in the lane were reached, it might be possible to keep silence; bnt the turn is still out of sight. If agricalture is indeed passing throngh the tail of the storm there is a terrible sting in the tail. Wheat continues to ponr into the country at a price with which English farmers cannot hope to compete; barley cannot be grown with profit; stock still shows a downward tendency; few farmers are able to make their rents. At a fat-stock market held within the last fortnight in the midland counties the highest prices which were realised ranged from $10 l$. to $12 l$. lower than those of 1885 ; and while $40 \mathrm{l}$. was the selling price of prize animals last ycar 30l. was the largest sum paid in 1886 . Money has been mado in inferior beasts which have turned ont well; it has been lost over the higher class. On Lord Exeter's Burghley estate fourteen tenants have recently given notice to quit; other Northants landlords, like the Duke of Bucclench, Lord Lilford, Sir Frederick Robinson, and Mrs. Stopford Sackville, are hardly in a better position. On the heavy land districts of Essex much land fell out of cultivation after the wet seasons of $1879,1880,1881$; most of it las since been bronght back 
into some sort of occupation; bat it is often let for sach grazing value as it produces, or is held on at nominal rents by tenants who are only bound to continne to cultivate and to pay the outgoings. The area of corn cultivation, if the price of horses affords any indication, is rapidly contracting. Farm horses, which in 1882 fetched 35l. a piece, are now sold for 10l. In some portions of the conntry farmers are leaving the sinking ship at any sacrifice, throwing up their farms, and realising what they can get. Six working horses, old, bat serviceable and good, were offered six weeks since in Peterborongh market at 30l. As yet agricnltural labourers have suffered comparatively little. But farmers can no longer afford to employ an adequate amount of labour. If nothing is done to relieve depression, hundreds of agricultural labourers will this winter be turned off to swell the starving and desperate mass of the nnemployed which fringes the borders of our glittering civilisation. Meanwhile all the profits of agriculture are passing into the hands of the butchers and the bakers. The price paid by the consumer is wholly disproportionate to the sum paid to the producer. It was suggested to me by a gentleman of considerable agricultural experience that if the Government fixed week by week the price of bread and meat on a fluctuating scale determined by the selling price of wheat and stock, together with an allowance of a fair profit for middlemen, they might not only redace the price of meat and of bread for the consumers, but impose a small import daty on foreign produce. Agriculture has reached so low a level in this coantry that in many districts it is almost an expiring industry. Under such circumstances the most rigid economists might defend the imposition of an import duty, provided that it can be accompanied by a cheapened loaf and a cheapened joint.

The present state of agriculture is a formidable danger to the property of the clergy. In moments of popular panic somebody is always hanged, and the victim who is dragged to the lantern is generally innocent. Necessity knows no laws; in stormy times the Church is a convenient Jonah for all political parties. Too many statesmen appear to think that the violation of established and fundamental laws is an evil of less magnitude than a political inconsistency or an avowed change of opinion. Men will drive a coach-and-four through a hundred Acts of Parliament sooner than bate one jot of their economical theories. It may be at once conceded that a pressure so severe as the present agricultural distress demands that the land should be as free as possible from all incumbrances. But nntil the clergy are placed in the same position as lay landlords and lay tenants, they hare not received fair play or enjoyed the same opportunities of 
doing their duty by the land. To force on a compulsory sale of glebe lands would at the present moment ruin parochial endowments; such a step could only be justified, if it were proved that the clergy, enjoying the same advantages as other landlords, neglected the duties and accepted only the privileges which belong to property. An inquiry into the effects on clerical incomes of agricaltural depression necessarily widens ont into an investigation of the peculiar conditions of clerical land-holding and a survey of the different schemes put forward in the interests either of the clergy or of agriculture. The resnlt of the whole will, I ventare to think, evoke widespread sympathy for the hardships of the clergy, establish a conclusive case for the extension to the parsons of advantages already conceded to lay landlords and tenants, and possibly incidentally suggest some reasons why legislators should hesitate before proposing or sanctioning hasty schemes for dealing with tithe rent-charges or glebe lands.

So far I have insisted only on the worldly pradence of bringing before the public the sufferings which the country clergy have undergone in consequence of agricultural depression. No one esteems a soldier who brags of his exploits, or values a parson who boasts of his virtue. Perhaps a layman's experience of the condact of the clergy under peculiarly trying circumstances may help the public to do more justice to a class which is tonguetied in its own defence by the highest motives of self-respect.

Within the last six years the clergy have had the opportunity of showing to the world an example of patient endurance of suffering. Witnesses examined before the Duke of Richmond's Agricnltnral Commission described the position of glebeowners as "deplorable;" since that date their position has steadily deteriorated. Yet their hardships have been borne without complaint, in silence, and with quiet dignity. The preservation of self-respect has been their sole reward. But when patience itself, as I have endeavoured to show, becomes the source of misrepresentation, it has been pushed beyond the point where it ceases to be a virtue. Many landlords have shown a most practical and generous sympathy with their suffering neighbours. They have taken the glebe lands into their own hands, have paid the fall rent to the parson, and borne the loss themselves. But it is only the wealthiest squires and men who enjoy an income derived from another sonrce than land who can afford to make such sacrifices. The relief, great though it has been, is necessarily so partial as only to tonch the fringe of the distress.

Many persous form as false an impression of the lives of the country clergy as onr ancestors conceived of the conditions of pastoral felicity. Strephon or Corydon in Chelsea china are as 
mach like the real shepherd as Old Leisure feeling his apricots on a sunny wall resembles the modern country parson. The different aspects which the same place may assume convey the lesson of the two aspects presented by clerical life. In spring or summer a prettily built parsonage, with fields sloping down to a bright stream, approached through cool lanes redolent with wild flowers, and resonant with the song of birds, is attractire enongh. When the sun shines it is a pleasure to feel that yon are six miles from the railway station; even the village street looks so quaint and picturesque and its inmates so cheery that it seems impossible for the clergyman ever to desire to exchange any extra-parochial thoughts. Visit the same place in the winter after floundering through lanes ankle-deep in mud, with a leaden sky overhead, and a north-east wind chilling to the bone or driving a sleety rain into your face. The only sigus or sounds of life in the deserted dripping village street are the beery steam which issues from the public-house, the wail of some half-fed child, or the shrill scold of an angry wife; the stream has made an ague-exhaling lake within a few feet of the windows of the parsonage, and it cuts the inmates off from their nearest neighbours by a flood which rans knee-high across the road. Outsiders are far too ready to forget that there are two sides to clerical life in the conntry, both in its material and in its spiritual aspect. Many men feel capable, when the sun shines, of a burst of momentary enthusiasm; bat they shrink from the constant discharge of daty which often cousists in a monotonons round of wearisome details.

All the temporal adrantages of the clerical profession are, at least in the midland counties, entirely removed. The clergy feel the pinch of poverty, not, perhaps, in its acutest form of actual hunger, bat in the loss of all those so-called laxuries which in their position and surroundings are really necessaries. First came inconrenience from delay and nncertainty in receipt of income; then the hamiliating necessity of asking for credit; then the certainty that rents would not be paid; then the pressure of creditors and the refusal to give further credit; then the expenditare of private capital and the mortgage of life insur. ances; then the application to friends. The honse and its surroundings are ill-adapted to a constantly narrowing income. The outdoor establishment is redaced, the garden cannot be maintained, the horse and carriage are sold. The same process is followed indoors. Servant after servant is discharged till not one is left; then follows the carefol hosbanding of fuel, the sererest practice of domestic economy, eren the disposal of books, furniture, and apparel. Sons are withdrawn from school or college, danghters are obliged to go out as governesses; life insurances are sold, pledged, or allowed to drop. Sometimes 
an effort is made to obtain pupils; but the connection of the clergyman with school or college has expired, and papils are hard to get; if they are found, the hard-rorked, dispirited parson doubles his labours and the home circle is invaded by strangers. More often than not no pupils can be obtained, and then begin the ghastly struggle to maintain appearances and the secret grapple with positivo want. The clergy have long had to deal with poverty as their only neighbour; it has now become their own constant and nnwelcome guest. Yet all the while, at very heavy personal sacrifices, the clergy have clung to their posts. The Church services must be maintained, and the curate's salary is paid by an incumbent who envies his subordinate his salary, and would gladly, if it were possible, step down in the clerical ladder. No one will give more than the parson, and the clergy are still obliged to head subscriptions to schools and local objects; the wants of the sick poor have still to be met by sonps and jellies and clothing. The farmers cannot afford to give alms, but the parson out of his scanty pittance must supplement the offertory with larger donations that its recipients may not suffer by its diminution. The parson is often the only man of education or refinement in the parish; he cannot seek the society of his friends, for he has no means of locomotion; he cannot solace himself with books, for he can no louger afford to bny them, or even to subscribe to a library; he cannot, like the sqnire, shnt up his house and leave the neighbourhood. He has no fellow-sufferer with whom he can compare notes; the farmers may understand his loss, but their well-meant sympatly is often expressed with excruciating frankness; the labourers grumble that he cannot employ them as he nsed, and is less able to minister to their wants. Yet, as has been said, the clergy have not only clung to their posts, but borne their heavy trial with an uncomplaining dignity which is worthy of their noble calling. Every temporal advantage of their position is disappearing; little remains to enconrage the parson in a life which has always had more than its nsnal share of disappointment, except his faith and the sense of sacred duties conscientiously performed. It may be that the resnlt will be to parify and elevate the character of the conntry clergy. If so, the refining process will nltimately raise their position and extend their influence, bat meanwhile the furnace is exceeding hot.

This is no fancied or exaggerated picture of the snfferings of the conntry clergy. In its entirety it is true only of individnals; but, if the clergy were not possessed of private means, it wonld hold good almost muiversally of glebeowners in the midland counties. It is npon those clergymen whose incomes are derived solely from land allotted in lien of tithe, that the blow has fallen with the greatest sererity. 
Bat the tithe rent-chargers have also suffered heavily. Their losses are by no means confined to the natural results of the fall in the corn averages. If this were all, they world have no ground for complaint. They have experienced difficalty where none has been experienced by lay impropriators in obtaining payment of tithes. In many cases it is impossible to collect tithes at all, and arrears have accnmulated for several years, the greater part of which are irrecoverable. In other cases the clergy have only obtained payment by consenting to a reduction of from 10 to 25 per cent., a course in which they are, in my opinion, ill-advised: any readjustment of the tithe rent-charge should be effected by Parliament and be general in its operation. But as compared with glebeowners, even ecclesiastical tithe rent-charger's have been in clover. Of all the classes interested in agricultare, whether landlords, tenants, or labourers, the losses of the glebeowners have been by far the most severe.

In the succeeding letters I propose to deal in detail with the effect of agricultural depression on the incomes of clerical tithe rent.chargers and glebeowners, to give instances and statistics in support of my conclusions, and finally to discnss the various schemes which have been proposed for the relief of clerical distress. 


\section{II.-THE EFFECT UPON THE TITHEOWNER.}

In my first letter I endeavoured to show how strong and widespread an impression was growing up that the parochial clergy are evading their fair share of agricultural loss, or barely tonch with their little fingers the heavy burden which has crnshed the landed interests. Because the clergy have been patient, long-suffering, and silent, it is supposed that they are in no distress. Under such circumstances they can no longer afford to hide their losses or to conceal their self-denying strnggles to do their daty both by the land and their profession. The condition of many of the conntry parsons, and especially of the glebeowners, is disastrous, if it is not absolutely rninous; no one who investigates the facts can continue to believe that they either enjoy immunity from agricultural distress, or refuse to extend a hand to sinking tenants. I hope to show that the clergy as a body are bearing an equal, and sometimes an excessive, share in the general calamity, and that, in the face of legal impediments, by which no other class of agricnlturists is hampered, they are striving at the cost of heavy self-sacrifices to meet the unexampled difficulties of their present position.

In this second letter I propose to deal with the clerical tithe. owners, to show how their incomes have been affected by agricnltural depression, and to discnss the honesty of the antitithe agitation. From the natnre of the subject and the very varying circumstances of different localities, only general statements are possible. Cases must necessarily occur in which many of my remarks cease to be applicable or reqnire large modifications.

It is possible that at the present moment titheowners, both lay and ecclesiastical, are suffering less than ordinary owners or occupiers of land. Though this seeming inequality is, in the case of clerical titheowners, with which alone I am concerved, more apparent than real, it is aggravated by political agitation and exaggerated by the results of the almost universal arrangement which renders occupiers liable for the tithe rent-charge. A popular feeling has been created against tithe which is with difficnlty removed. Farmers themselves believe that they pay the tithe ont of their own rednced capital; they see that the present value of the charge is disproportionate to the prices they themselves reccive for corn; and they naturally resent the payment. In point of fact tenant farmers have as little to do with tithe as they have with the land-tax; they are merely its transmitters, the conduit pipes through which landowners pay 
it to titheowners. The Tithe Commutation Act of 1836 treats the tithe as a landlord's charge, a charge upon the land, and not a burden upon its produce. Landlords cannot be acquitted of a large share of the blame for tlie present resistance to the pay. inent of tithe.

The area over which the anti-tithe agitation extends widens rapidly. In Wales the payment of tithe is a bnrning question. Yet, agriculturally, there is less reason for the agitation in Wales than in England. The tithe is generally less than in this conntry : and the Welsh farmer, till within the last two or three years, weathered storms which wrecked hundreds of English tenants. In the Principality the agitation is stimulated by political causes and fomented by Dissenting ministers and the proprietors of vernacular newspapers. It does not fall within my province to discnss the character of a local movement which is directed less towards relief from an agricultural grievance than towards the disestablishment and disendowment of the Church in Wales. In the English counties the movement is more purely agricultural, though even here it often assumes a political aspect. Before the pressnre of agricultural distress commenced, no opposition was made to the payment of tithe; and it is therefore to this cause that the present agitation is mainly due. Drowning men clntch at straws; farmers welcome any prospect of relief from the disbursement of cash; many are sincerely convinced . that they pay tithes not as part of, bat in addition to, the rent.

If the only remedy proposed for the present agitation is that the tithe should be paid by the landlords farmers will scarcely be satisfied. They paid the tithe while it was rising; now that it is falling they are told that it will be undertaken by landlords.

Resistance to tithe is spreading rapidly in England; it is enconraged for their own purposes by political tramps; it is even in someinstances supported by landowners. Along the Welsh borders, in Monmonthshire, Herefordshire, and Cheshire, opposition has already made considerable progress. In Kent the Extraordinary Tithe Redemption Act of 1886 (49 and 50 Vict., c. 54) has diminished the unpopalarity of one form of tithes, though it cannot be said to have satisfactorily settled the question. But ordinary titheowners have also encontered great opposition in the collection of their tithes. Tithes in Kent are extremely high ; and the incongruities, especially in such districts as Romney Marsh, exceptionally great. Rich pastnro which makes the rent pays a modus of Is.; and arable land on the other side of the hedge, which is often a dead loss to the farmer, pays a tithe of 12s. an acre. The difference arose from the difficulty experienced in taking a tithe of grass; the titheowner accepted a customary payment called a modus decimandi in lien of his tenth. These arrangements were left untouched by the 
Titbe Commissioners in 1836. Remissions have been made on many estates, and by many clergymen, of 10 and 15 per cent. In all abatements, or claims for abatement, the reduction is made not upon the par value, bnt upon the 90 per cent. which represents the present value of the tithe rent-charge. In Hampshire farmers demand a reduction of 25 per cent. on the tithe; their demand has not been acceded to, and at Andorer they have opened a subscription list to resist any action taken for the recovery of the charge. In Essex large arrears have accumalated through the unwillingness of titheowners to apply the cumbrous and unpopular means of enforcing payment which the law provides. Considerable sums have been altogether lost to titheowners through the operation of the Statate of Limitations, or through the land falling out of caltivation; in many cases payment has only been obtained on the condition of abatements of from 10 to 20 per cent. At the present moment a general tithe war is imminent in the county. Redactions of 20 per cent. have been asked by the tenants of Hatfield Broad Oak and of Great Bardfield. In both cases the titheowners, Trinity College, Cambridge, and Guy's Hospital, have refused to make the reduction claimed. The Essex Chamber of Agriculture recently resolved that a revaluation and reapportionment of the tithe was rendered imperatively necessary by the depreciation of land and the value of its products. Elsewhere in the east of England, in Lincolnshire, Norfolk, and Suffolk, there is but little opposition to the payment of tithe. In the midland counties scarcely any difficulty has been experienced in the collection of the money; this class of property is comparatively rare; the persons interested in resistance are few and scattered. Yet, even in these favoured districts, abatements have been asked and given of from 5 to 15 per cent. Agricaltural depression and political agitation combine to make the country as inflammable as touchwood. If once resistance takes a hold on a county it will spread like wildfire. Yet, apart from the political question with which the movement is associated, and apart from the advantages of emancipating the land from all fixed charges, no thinking man reasonably acquainted with the natare and history of tithes can sympathise with the anti-tithe agitation or uphold its jnstice.

I have said that at the present moment titheowners, both lay and clerical, are perhaps better off than other landlords. The rent-charge payable this year is possibly more than the titheowner would realise if he still continued to take a tenth of the gross prodnce of arable and pasture land. In any such comparison the amount of produce which is wasted in removing and honsing a tenth taken in kind mast be considered. The tithe rent-charge may be more than the titheowner would have realised under the old system; it is probably not so much as 
the landlord wonld have lost. Even if it were conclusively proved that the tithe rent-charger now enjoys the best of the bargain, and that the diminution in the value of his share of the produce, as shown by the tables, does not equitably represent the share which he ought to bear in the diminished value of the total produce, it by no means follows that his share in the general barden is disproportionately small.

In the first place, titheowners are still receiving their shares, hitherto nnpaid, of previous prosperity; at the time they profited less by the increment than any other agricultural class; their profits are, from the nature of an income which is calculated on arerages, spread over several years. In the second place, although war may in the interval send corn up to famine prices, titheowners will continue for the next seven years to suffer from the recent period of distress. So long as the existing arrangements are maintained for the payment of tithes between landlords and occupiers both these considerations introduce an apparent element of injustice into the position of tenant farmers If a farm changed hands the farmer who rents in bad times is paying tithes which are abnormally high owing to profits reaped by his predecessor. Even this appearance of injustice conld not exist if landlords had acted up to the spirit of the Commutation Act of 1836 . Neither the profits nor the losses of titheowners are immediate; both are spread over a considerable period of years. Many other considerations must be borne in mind in estimating the amount of the clerical titheowners' share in the general burden. Large arrears are accumulating, the amount of which is not adequately represented npon the books, becanse large sums are now irrecoverable; considerable abatements have been made, varying from 5 to 20 per cent.; tracts of land hare fallen out of cultivation, upon which tithe ceases to be payable; rates fall with increased severity npon tithes in proportion as the assessment value of farms decreases with the reduced rental. Lastly, clerical incomes are subject to pecu. liarly heary dedactions for the payment of curates and the conduct of divine service, the repair of chancels, the support of schools, the maintenance of local clnbs and societies, and the administration of charities. This last class of professional outgoings may be almost regarded as absolute charges upon the income of the clerical titheowner; the money which they repre. sent is spent in and for the benefit of the parish; and the burden falls with greater weight upon the parson in consequence of the increase iu the surrounding poverty.

Figures are generally misleading; bnt they render abstract statements more concrete and definite. The total value of tithe rent-charge, as commuted and apportioned in 1836, is in round numbers four millions. Of this three-fifths, or $2,400,000 l$, are in 
possession of clerical incumbents. From this sum may be deducted 5 per cent. for collection (120000l.), 10 per cent. for the fall in 1886 from the par valne (24.0,000l.), 10 per cent. for rates and taxes $(240,000 l$.), 5 per cent. for arrear's, abatements, and other losses $(120,000 \mathrm{l}$.). The net value of the rent-charge received by clerical titheowners is, therefore, 2,400,000$720,000 l=1,680,000 l$. From this sum mast be deducted 20 per cent. for the almost absolute charges which fall upon parochial incumbents. The snm which represents the real value to the parsons of the tithes may be estimated at $1,680,000 l$. $336,000 l .=1,341,000 l$. The two donbtfnl figures, the 5 per cent. for arrears, \&c., and the 20 per cent. for clerieal outgoings, are probably considerably below the mark; aud it may be doubted whether the ultimate value to incumbents of the tithe greatly exceeds a million pounds a year.

In estimating the losses of landowners and tenants one standard by which the loss is measured is the selling valuo which their respective properties previously possessed. If the sane test be applied to tithes, the loss will be far greater than the amount at which it has been calculated above. Thus the selling value of a tithe rent-charge twelve years ago was 125 per cent. If the loss of the titheowner is measured by the difference between 125 per cent. and the present par value of 90 per cent., minus 5 per cent. for arrears, \&c., it represents a loss of 40 per cent. Sir James Caird estimated the agricultural loss last jear as compared with ten years ago as follows:-Landlords, 30 per cent.; tenants, 60 per cent.; labonrers, 10 per cent. The relative positions of the losers will probably remain much the same in 1S86-7. Upon this scale titheowners raise the arerage of loss in their class; among laudlords at least they are bearing an equal share of the burden. In comparison of their 40 per cent. loss with the 60 per cent. loss of the tenants elerical titheowners are cntitled to pray in aid the heavy dednction of 20 per cent. which is made from their incomes for parochial purposes.

In discussing the advantages of the redemption of tithes it mast be remembered that the income of the incumbent is the only income which is and must be spent in and for the parish. From this point of view the testimony of M. de Lavergne as to the effect of the abolition of tithes in rural distriets of France is not withont its value :-

"Cette suppression des dìmes a eu en réalité bien moins d'importance qu'on le eroit. La eharge a été déplacée non détruite. . . . . Le clergé y a perdu en tout une vingtaine de millions de revenu; mais croit-on que eette somme les contribuables l'avaient gagneé? Je ne serais pas bien embarrassé si j'avais a désigner dans notre budget actuel, non pas vingt millions, mais cent, moins utilement dépensés dans l'interêt des campagnes que le produit des anciennes dîmes. D'un autre côté, la rente du sol s'est accrue en général du montant des dîmes et les cultivateurs, propre- 
ment dits, à l'exception de ceus qui étaient proprié caires, n'ont r.en gagné." - (Economie Rurale, \&c., p. 8, ed. 4, 1874.)

If the question of tithes is regarded from the broadest point of view of national interests, is it absolutely certain that the nation would gain by their so-called abolition? History might be searched in vain for an instance in which the plander of Churches put a penny into the pockets of the people.

I have said that the question of tithes is really onc between landowners and titheowners; and I have endeavonred to show that the arrangement into which tenants enter to pay tithes introduces an apparent element of unfairness. On the other hand, it must be remembered that the farmer has hired his farm with the full knowledge of the amount of the rent-charge, sub. ject only to the fluctuations in the septenuial averages, and that for the last few years the fluctuations hare been continuously downward and to his adrantage. The farmer has assumed the responsibility for the tithe, against the interest of the titheowner, and against the policy of an Act of Parliament. So long as the arrangement was to his advantage he remained silent; now that it has turned against him he complains, and often honestly, of the incidence of the charge. In 1868 the titho rent-charge was only worth $100 \mathrm{l}$. 13s.; but the actual value calculated on the price of corn for that year was $125 \%$. Did the farmers think it necessary then to pay the difference? Will they, supposing that a war sends ap prices, think it their duty, if they are now granted abatements, to pay the tithe rentcharges calculated apon the prices of corn in each single year of agricultural prosperity? The titheowner did not profit to the natural extent by the "piping times." It is hard that he should now be asked to share in the loss when he was never offered a share in the gain.

Many objections are taken to tithes. Some of them are wholly frivolous. It is difficult to suppose the statements that tithes raise rents or lower wages to be seriously entertained. Half the land in England is tithe-free. In Northants, for instance, there is scarcely any tithe. Are rages higher in this connty or rents lower? Do farmers who rent tithe-free farms pay more to their labourers than their neighbonrs who occnpy land subject to tithe? Does a yeoman, farming his own laud tithe-free, give higher wages than those who pay both tithe and rent? Neither do tithes raise rents. A 13 rents a furm of 100 acres at $1 l$. an acre. It makes no difference to him whether, if his land is tithe-free, he pays the whole rent to the squire, or, if it is subject to tithe, 18s. to the squire and $2 \mathrm{~s}$. to the parson for every acre in his holding. The farmer's position is exactly that of a London honseholder, who, in addition to his rent to the lessor, pays a gronnd-rent to the gronnd landlord. A house is let 
to A B for 250l.; it cannot make an atom of difference to him whether he pays $50 l$. of this rent as ground-rent to the ground landlord, or pays the whole rent to the landlord, who himself satisfies the claim of the owner of the soil. Other objections possess greater weight. But the Act of 1836, by which the tithe was commuted and apportioned, has been for half a century treated as a final settlement of the question. Land has been bonght and sold and tithes have changed hands upon this understanding. It is perilous to tamper with the security of property. But, subject to this general cantion, it may remove misconceptions if some of these objections are examined.

It is said, for instance, that titheowners are better off under the rent-charge than they would be if they continued to take tithes in kind. Such a comparison is difficult to institute; it is, in fact, impossible, becanse it is inconceivable that modern notions of property conld coexist with the practice of taking tithes in kind. Men often talk as if corn was the only produce which affects the question. But in all cases in which the provisions of the Act were not superseded by volnntary agreements the method adopted took into consideration the gross value of tithes in kind of the prodnce of meadow, pastare, and arable land, of the tenth pig, the tenth cock of hay, the tenth pail of milk, the tenth fleece, the tenth egg, the tenth calf, the tenth lamb, as well as the tenth sheaf of wheat, barley, or oats. The average annual ralue of all tithes paid in kind during a period of seren years was ascertained, and the amount, subject to certain deductions within a specified margin, was taken as the sum to be paid as a permanent composition on the lands of the parish. The sum thus ascertained and fixed was then commuted into a corn rent. The sum was divided into three equal parts, and respectively apportioned to wheat, barley, and oats at the prices per imperial bushel of $7 \mathrm{~s}$. $0 \frac{1}{2} d$. for wheat, 3s. $11 \frac{1}{2} \mathrm{~d}$. for barley, and 2s. $9 \mathrm{~d}$. for oats. The quantity of corn was fixed by the purchasing power of the sum which was the ascertained annual value of the produce in kind; the money henceforth to be paid by way of rent-charge raried with the value of the fixed quantity of wheat, barley, and oats. The result of this system is that, in order to compare the relative positions of titheowners in 1836 and in 1886, it is not sufficient to ascertain the different values of corn, but the present valne of all prodace in kind on which tithe was then payable must be estimated. Farmers often claim that the corn rent was fixed at Protection, not at Free-trade, prices; but it is obrious that at the prices of to-day the purchasing power wonld be increased, and the fixed quantity of corn apportioned to the land would be larger. Similarly it is complained that the tail corn is not now taken into account in estimating the septennial averages. But 
in 1836, if tail corn had been inclnded in the estimate, the tithepayer would have suffered, becanse the fixed quantity which the money wonld have porchased would have been increased. A more valid objection seems to be that oats and barley, from their cheaper prices and larger quantities, have exercised an undue preponderance in the calculation of the averages. While wheat fell enormously, barley and oats till recently made their old prices, and thns negatived the effect upon the averages of the fall in wheat. If railway rates and other charges for the carriage of corn swell the prices on which the averages are calculated, a case is established for a change in the method of ascertaining the amonnt of the tithe rent-charge. This is an innovation which the Act of 1836 did not contemplate. But, subject to this possible exception, for half a century sales have been determined, contracts entered into, bargains strack, valuations made, on the system established by the Tithe Commutation Act. Tenant farmers are not really concerned in the adjustment of the tithe rent-charge, and, as between tithcowners and landowners, who are the only persons concerued, the landowners have enjoyed the best of the bargain.

As between landowners and titheowners it must be remembered that since 1836 rents have nearly donbled; before the Comnutation Act a tenth of this increment would have gone to the titheowner. Sir James Caird clearly shows how the Act has operated to the detriment of titheowners. The effect of the $\Lambda$ ct was to prevent the clergy progressing in material resonrces in proportion to the advance of land improvement. Whether or not this was the intention of the Legislatnre, the result cannot be considered unfair since titheowners do not in any way contribute to agricnltural progress. Since 1836-

"The land rental of. Eugland has risen 50 per cent,, and all that portion of the increase which previous to 1836 would have gone to the Church has gone to the landowners. . . . A tenth of that would not, however, by any means adequately represent the loss to the Church and the gain to the landowners; for the tithe in kind was the tenth of the gross produce which was equal to much more thin a tenth of the rent of arable land. In 1836 the money value of the tithe, as compared with the land rental, was as 4 millions to 33 . In 1876 the tithe was still 4 millions, but the land rental had risen to 50. If the old principle of participation had continued, the aunual income of the Church would have been 2 millions greater than it is." -(The Landed Interest, p. 133, Fourth Edition, 1880.)

In another respeet Sir James Caird shows that landlords have profited at the expense of the Charch. Near large towns land has increased in value 100 per cent. :-

"It was never contemplated," writes Sir James, "that the landowners should thus obtain the whole growing value of the land withnut leaving any part of it for the support of religion " (p. 135).

The alliance of landorners with tenants in the anti-tithe 
agitation $s$, in my opinion, short-sighted, if it is not actually dishonest. Landowners bonglit their land at a less price becauso it was subject to tithe; they never purchased or acquired tho rent-charge; it can be no grievance for then to pay what never belonged to them; it is no hardship not to receive intercst on capital which they have not invested. Their successors inherit what their.predecessors bought, neither more nor less; they are in exactly the same position with respect to the charge, neither better nor worse. The alliance is foolish, because the confiscation of tithe will necessarily shake the security of every form of property. It may be true that tithes are sacred to purposes, while private property is sacred to persons; bat the varions forms of property are so inextricably connected that a blow which is struck at one inevitably wounds the whole. The security of all property would be endangered if a form of property, which is the oldest in the country, were diverted from objects which are ex hypothesi usefnl and beneficial to purposes of a different if not antagonistic nature. The allianco is foolish for two other reasons. If "abolition" meant that for the futnre no one should pay tithes, landlords would receive a present of the amount. The nation might gain indirectly by the unrestricted ownership of the land. Bat it is absolntely inconceivable that in the latter end of the nineteenth century a proposal would be made to enrich landlords with a pecuniary benefit of so large an amomnt. Whaterer is done with tithes they will not be in this sense abolished. They will be exacted by Church Property Commissioners instead of parsons; the new collectors will not be hindered by any conflict of duties in their appeal to the law; no grace will be allowed; and every facility will be given to Government officials to enforce payment. Landlords assuredly will be no gainers if the right to tithes is transferred from the clergy to an all-powerfnl machine which knows no mercy and allows no plea for delay. Again, if the clerical tithe rent-charge is transferred to secular uses, what argument can be pleaded for the retention of lay impropriations? Titbes in the hands of laymen are the proceods of the dissolation of the monasteries, of endowments which enabled monastic establishments to be schools, penitentiaries, asylums, and poor-houses. There is no pretence for asserting that the original purposes of the donors are fulfilled. The same cannot be said of parochial endowments; the conntry clergy still perform the daties for the performance of which parochial tithes were originally appropriated. No distinction can bo drawn between tithes paid to the clergy and tithes paid to laymen, except that the former earn them, while the latter do not. To most minds both forms of property are equally inviolable. 
But lay tithes, if any degree of comparison in their sanctity as property can be admitted, are infinitely more open to attack.

From what has been said it will, I hope, be conceded that clerical tithcowners are noither apathetic nor relieved from agricultural distress. The tenant farmer is not really concerned with the solation of the question; and it is obvious that the clergy have every right to demand that the landlords should carry out to the very letter the spirit of the Tithe Commatation Act of 1836. The present position of clerical titheowners is painfnl to the extreme. They are dependent on bankrupts for their bread. Their position as spiritual advisers is seriously compromised when they at the same time appear as creditors pressing struggling tenants for payment of tithe. The dilemma is one in which the clergy ought not to be placed; it is one which the law never intended them to occupy; it is one into which landlords and tenants have thrust them for their mutual advantage. Many suggestions have been made in tho interests of agricultare, or of the Church, or of the landlords, or of tenants for the redemption of tithe. T'he wholesale confiscation of tithes is a proposal which is not likely to be seriously entertained; it is put forward by its advocates on the principle which prompts a dealer to ask twice as much as he intends to take. I reserve the discussion of the proposals which may bc considered as really before the country for my final letter.

Meanwhile the position of the clergy is peculiarly painful. Their incomes are small ; the claims upon them are already large, and are increasing under the pressure of agricultural distress. To many of them reductions or remissions mean sheer want, or the abandonment of one or more of their spiritaal agencies. It is infinitely to their credit that they have preferred to starve themselves rather than the Church. The loss of income conseqnent on the fall of the averages means the differenco between comparative comfort and a straggle to make both ends meet. The clerical titheowner is at the same moment called upon to exercise a more abundant charity : he, as it were, buys want out of the labourer's cottage by offering her a home in his own honsc. This is the opportunity which is seized to demand from the clergy a further reduction in their already narrowed incomes. The alternative which is presented to them in many parts of the country is the absolute refnsal of any tithe at all. The temptation to secure some payment by granting abatements is necessarily great; in many cases their credit is pledged and they are themselves pressed for payment. So, again, the condition of the tithepayer is, as they well know, disastrous; the tithe may be the last straw which will break his back. Between want at home and want abroad, how ought they to act? The clergy are, in my opinion, most ill advised if they grant abate- 
ments of the tithe It is their obvious duty, by the benefice which they hold, as well as by a Church which still has a future before it, that they should maintain the income nndiminished. They may have a logal right to make reductions; but they have not, in my opiuion, any moral right. When once they have collected the tithe, their daty by the benefice is performed; they may do what they like by their own. Public policy condemns reductions of the tithe; it has nothing to say to the most unbounded exercise of private charity. Whatever is to be dono for the adjustment of the tithe question should be done by an Act of Parliament, generally, and once for all. 
III.-THE EFFECT UPON THE GLEBEOWNER.

Anciontly all the land of the country held by laymen was subject to the obligation of paying tithe. Unless a special exemption could be proved there was no lawful discharge from the duty. Bat at the present day half the land in England is freed from tithe rent-charge; in some districts it is scarcely known. Under the Enclosure Acts, which were so numerons at the close of the last and the commencement of the present century, lands were assigned to the clergy in lien of tithes. The value of a tenth of the produce was commuted, not in a corn rent, but in land. Perhaps, in the strictest sense of the word, the lands thus allotted are not glebes; but it is to the lands which were given to the clergy instead of tithes that I refer throughout the following remarks. In the Midland counties, and especially in the dioceses of Peterborongh and Ely, very little ecclesiastical property is held in tithe rent-charges. Clerical incomes are almost entirely derived from the rental or other profits arising out of glebe-lands.

It has been said that as compared with glebeowners tithe. ownors are now in clover. On the other hand, in times past, glebeowners benefited to the full by the increase in the amount and the value of agricaltaral produce, which within fifty years doubled the rental of land. The effect of the Tithe Commutation Act was to deprive titheowners of their proportionate share in this increment. Titheowners derive from the land the limited profits, and onght now to suffer the limited losses, of rent chargers; glebeowners enjoyed the natural profits, and now, as I hope to show, suffer more than the corresponding losses, of landowners. The incomes of glebeowners swelled enormonsly by the exchange of tithes for land in the "piping times" of rural prosperity. The fortunate Midland incumbent not only possessed the moral adrantages of his professional position; he also enjoyed the social prestige and the conntry pleasnres which were the monopoly in the far-off days of agricultaral felicity of the landed squirearchy. A complete revolntion has been accomplished; the scale of the glebeowner's prosperity has kicked the beam.

To the incumbent the possession of land has often become an intolerable barden which alienates his parishioners, narrows the sphere of his influence, clogs and impedes him in the adequate performance of his clerical duties. It identifies him with the farming interest, to which in many rural districts the majority of his parishioners are opposed. If he lets his glebe farms he 
cnter's on the delicate relations of a landlord towards distressed tenants. In these days every farmer is more or less in arrear or difficalty. The door of a debtor is closed in the parson's face whether he knocks as a minister or as a creditor. Appeals for repairs and improrements are made to him in his capacity of clergyman, of which he would hear nothing if he were a lay squire. How can he preach charity and mercy to his tenants, when he has instrncted his solicitor to distrain or given them notice to quit their holdings? How, on the other hand, is he to live if he does not get his rent? If he shows indalgence to a struggling tenant, whose moral character is praisewrorthy, he not only loses money himself, but he injures the labourers. When farmers fall into difficulties, they cannot employ sufficient labour. The "wet and dry" man eurses the parson for his leniency; but the moment a tenant is dismissed, he is the first to make a personal application to the clerical landlord of the parable of the unmerciful servant. If the incumbent farms his land himself, he is obliged to keep on lazy or bad workmen, because he knows that no man whom he discharges will ever again darken the doors of his church. From first to last he is obliged to set off against his certain loss as a landlord the possible spiritual benefit which he may confer on his tenants and his servants. He is perpetnally impaled on the horns of a dilemma; if he exercises forbearance he injures himself and his land; if he enforces his rights he loses his spiritual influence. With him it is a case of "Heads you win, tails I lose." He is certain to lose his income or his popularityor both. I have said nothing of the mental anxiety and ceaseless worry of farming basiness. The land must at least distract his attention, if it does not end by absorbing his interests.

The Legislature has wisely set its face against the modern revival of Parson Trulliber. Mach of the enthusiasm of the older race of clergy was spent upon the due rotation of crops. In the beginning of this century an Archdeacon visited a charchyard which he found cultivated for barley. Turning to the rector he said, in a tone of severity, "This must not occur. again." "Ol, dear no!" returned the bncolic rector, "it will be turnips next year." An Act passed in the present reign shows the desire of the Legislature to direct the cnthnsiasn of incumbents into more professional chanmels than those of farming or of trading. But the Committee of Conrocation upou Clerical Incomes, and those of the clergy who have accepted the report of that body, are, in my opinion, entirely mistaken in their reading of the statnte in question (1 and 2 Victoriae, c. 106, ss. 28-31). But whaterer is its true constrnetion it plainly intimates the intention of the Legislature to prevent the incumbent sinking his clerical duties in his farming propensities. 
On the meaniug of the statute I shall have something to say in my final letter. At present it is sufficient to point out that the examples of the past, the policy of modern law, and the experience of the present coincide. They clcarly indicate that the extension, or, indeed, the continuance, of the system of clerical farming, which is a necessary but deplorable result of recent agricnltural depression, is prejadicial to the best interests of the parochial clergy.

As I have before said, glebeowners have not murmured against their reverse of temporal fortune, however much they may regret its indirect effect upon their spiritual influence. Mere repining is as useless as it is unmanly. The craving for sympathy, if pablicly expressed, produces a complete revulsion of feeling, or at the most excites a pity which is largely mingled with contempt. The clergy have preferred to maintain silence respecting their heavy losses and deprivations. No well-wisher to the Chnrch would desire to drag to light the private affairs of the parochial clergy, or to parade their misfortunes in the hope of exeiting compassion. Self-respect would reject any expression of sympathy, aroused by such means, as little short of insult. But many reasons render it prudent that the truth shonld be told respecting the effect npon their position of recent agricultural depression. Two will suffice. First, a false construction has been placed upon their silence, sometimes in ignorance, often by design; secondly, the peculiar difficnlties by which glebeowners are impeded in the cultivation of their land are not only misunderstood or ignored, bat imperatively require removal.

In these days of highly spiced literatare local colour and vivid description are almost essential to force and effect. General statements are by comparison flat and spiritless. The temptation is great to indulge the public taste-by painting with a full brash and warm glow of colour telling scenes of clerical poverty. The material is abnndant, the pigments bright and varied. But I venture to think that I shall best meet the wishes of those who have given me information if I continue to treat the sabject in the style rather of the parti grisatre than of the parti famboyant. Description and local colonring may, and probably mnst, lead to the identification of places and of persons. Abstract statements possess at least onc advantage-they preserve the incognito of those who have only given information on the distinct understanding that names shall not be directly or indirectly divulged.

I propose in the following letter to illastrate the extent to which glebeowners have suffered from the prolonged agricultural depression, and to indicate one of the chief reasons which has caused the blow to fall upon them with exceptional 
severity. The fuller treatment of this latter part of the subject I reserve for my final letter.

The present position of glebeowners is disastrous and often rninous. Attention has been frequently called to their condition. Witnesses examined before the Dake of Richmond's Agricaltural Commission described it, even in the early years of the present depression, as "deplorable;" it was made the subject of an inquiry by committees appointed at diocesan conferences in the dioceses of Ely, Norwich, Peterborough, and possibly elsewhere; upon petition of the Rural Deans in the diocese of Peterborough, a committee of Conrocation was nominated in May, 1884, " to consider the present state of the law as affecting incumbents dependent for their incomes on land." Finally, a return is before me which shows the depreciation which has taken place between 1880 and 1886 in the net value of all the livings in Episcopal patronage in one of the midland dioceses.

The committee appointed by the Diocesan Conference of Peterborongh in 1881 received 336 returns from the clergy within the diocese, representing 49,629 acres of glebe lands. They reported that " 9,373 acres were in the hands of seventynine clergy from inability to find tenants;" and that "glebe rents had generally nndergone a reduction of abont 25 per cent." The committee of Conrocation nominated by the Prolocator in May, 1881, issued its report in March, 1885. They received nearly 500 returns from benefices in the dioceses of Ely, Peterborough, St. Albans, and Salisbury. The general result of the incuiry showed that glebe lands had depreciated in valne "from 43 per cent. of the previously received incorne from this source in the archdeaconry of Huntingdon to more than 25 per cent. in the least affected districts." Finally, the abore-mentioned retarn of the depreciation within the last six years of the valne of the livings in Episcopal patronage includes nearly 100 bencfices. Some of these livings are town parishes; others have been augmented by Queen Anne's Bounty, the Ecclesiastical Commissioners, or the Diocesan Society. The remaining thirtyfour parishes show a reduction of rather more than 25 per cent. between the net value in 1880 and in 1856 .

Bat the redaction in rent, heary though it is, by no nreans covers the whole of the loss which the clergy have sustained. In 1881.197 clergymen in the diocese of Peterborough made returus of having spent from 1870 to 1880 (in round numbers) $75,000 \%$. on the improvement of farms and buildings. Of this total sum, 38,000l. was raised by loans from Qncen Anne's Bounty or land improrement companies. The remaining $37,000 l$. was private capital, snnk in the land without a shadow of security for the principal, and with but slight prospect of any 
interest on the investment. In 1885 the Committee of Convocation reported that private capital to the extent of more than $50,000 l$, had been invested in the glebes, without any security, by the incambents of the diocese of Peterborongh alone. If the ratio which existed between the two sums in 1881 were adequately maintained, the private capital was met by a similar sum raised upon loan. There is every reason to believe that considerable sums have been spent from private sources in the two years which have elapsed since the committee of Convocation issued their report. Thus, in addition to a reduction of rent which in 1884 varicd between 43 per cent. and 25 per cent., the incomes of glebcowners are diminished by annual charges for interest and repayment of loans to the amount of $50,000 l$., and are at the same time lessened by the almost entire loss of interest apon private capital of the same amount.

Two years have elapsed since the returns were made to the committee of Convocation, and the interval has rather witnessed a deterioration than an improvement in agricultural prospects. More private capital has been expended and more money charged upon livings for the interest and repayment of loans. Rents continue to require reduction, and glebe-lands are still unlet. But these considerations by no means exhaust the whole of the glebeowner's loss. It is a serions matter that his rental steadily falls, while the charges upon his income increase and his private capital dwindles. But it is not everything. Heavy arrears of rent have accumulated which have been totally lost, together with the taxes paid upon them in advance. Other arrears are still nominally recoverable at law, but the payment cannot be practically enforced, because the tenant has lost his capital and there is nothing worth a distraint. If the glebe farm has been let, the incumbent has probably incurred the expenses both of the landlord and of the incoming tenant. As landlord he has paid the quitting tenant compensation for unexhausted improvements; he has also been compelled to take to the valnations as if he were himself the incoming tenant. If he is fortunate enongh to relet his land, the new tenant altogether ignores the valuation, and probably demands to occupy the land rent-free for the first six months of his tenancy. Still more unfortnnate is the lot of the incumbent who has his glebe thrown apon his hands. If he farms the land himself, he probably takes to it in bad condition, foul and impoverished; consequently he must expend more labour upon the soil in order to recover it, and he does so at a tine when stock or farm produce is falling in price. It is no light matter for a life tenant to borrow capital and stock a farm. He is a bold man who does so without experience and without the secarity which every tenant now enjoys for nnex. 
hausted improvements. Ho is an exeeptionally lacky man if he does not lose his capital as well as his rent. But what is he to do? If he does not let or cultivate his glebe he must either resign or starve. In some cases an incumbent was saved from this last fate by a subscription among his neighbours. Bat snch generous interpositions are necessarily rare.

Thero is every reason to believe that the year 1856 will prore the most disastrous of the series of ruinous seasons. The conntry has not yet appreciated the full extent of the mischief of the prolonged agricaltaral depression. Many farmers are holding on in hope of a turn, with exhansted capital, employing less and less labour, unable to prevent their land from becoming jear by year more foul and poverty-stricken. If the tarning-point is not yet reached, if farmers have not yet tonched bottom, more and more land will be thrown np, or heavier reductions of rent will be required. Mr. C. S. Read's gloomy prugnostication secms entirely warranted by facts, that if tenant-farmers continue to lose at the rate at which they have recently lost, there will not in the next ten years be one tenant-farmer left in the country. The bare existence of most of the glebeowners is bound up with the revived prosperity of tenant-farmers.

Sometimes the income of livings has been so rednced that it has entirely disappeared; it is swallowed np by charges for the repayment of loans and other outgoings. Sometimes rents have altogether ceased because incumbents have allowed their glebes to fall out of cultivation sooner than face the loss which they would inevitably incur as farmers. In two cases even the land itself has gone, and the benefice has been wholly disendowed. In Bedfordshire a land improvement company was compelled to foreclose its mortgage and sell the glebe in order to recoror its money. Similarly in Cambridgeshire the glebes of the benefice were charged with a loan advanced for drainage and farm buildings. Rents fell; arrears of the annual payments accumulated; finally, the company, or its assignee, sold the land in order to repay its loan. At this moment on a glebe in Lincolnshire a similar crisis is approaching. The glebe consists of 374 acres. The old rental was $680 l$. It is subject to a charge of $223 l$. to a land improvement company. The land is nnlet; all the payments are in arrear; and there is, apparently, no alternative bat the sale of the whole or part of the glebe. Under suce circumstances it is not sarprising that in many parishes it is difficult to provide for the spiritual needs of the people, or that many glebeowners do not obtain bread and cheese from their benefices, or that the description given in my first letter holds good in its entirety of some clerical landlords. All that was said respecting the almost absolute charges which fall upon clerical titheowners applies with equal force to glebeowners. They are obliged to occupy houses built 
in better times and not adapted for uarrow incomes; to keep in repair the chancels of churches reared at no penarious scrutiny of nicely calculated less or more, to maintain the provision for divine service, to head local subscriptions, to dispense an abundant charity. Their incomes wane and their professional outgoings wax each snccessire year of their distress. Meanwhile rates fall npon them with increasing sererity, mocking their position by their assessment upon an income which they have long ceased to receive.

Naturally glebe livings are difficalt to fill, when the incumbent has to draw upon his private income for the privilege of per. forming his spiritual duties. As a dignified ecclesiastic said to me, "I have to hawk about my livings in the advertisement colnmns of the newspapers." One so-called benefice has remained racant for three years. The proper form of advertisement for a glebe living in the midland connties would be- "Wanted, an experienced farmer, with capital and in holy orders, to take a farm of 500 acres, with rectory attached." More than once I heard the expression, "If I had not private means I should starve." Nor was this a figare of speech: it represents a grim fact.

Before illustrating by examples the effect of agricultural depression upon the incomes of glebeowners, let me advert to a point which has impressed me forcibly. It is the immense difficulty of collecting accurate and clear statistics which shall be nnmistakable in their effect. The retarn of Episcopal patronage, to which I have before allnded, is a case in point. Upon its resnlts it might be argued that glebe-livings have only depreciated 25 per cent. There is nothing in the retarn to support this conclasion. It mast be remembered that there has been no good agricnltural season since 1874, and that, if the depreciation had been calculated on the last twelve years, instead of the last six, the amount would be far greater. Also, there is no retarn to show whether the income of these livings is derived wholly from glebe or wholly from tithe or from both; or whether the valne has been increased by snch windfalls as sales of land to railways, or wayleaves to ironstone com. panies-accidents which do not affect the question of the effect of agricultural depression, but which hare sared several glebe incumbents from comparative rain. Also it is often almost impossible to estimate the net valne of a glebe-living at any one moment of time. If the land has been in hand for a year, or has been relet on the condition that for six months it should be rent-free, or an arrear has accumnlated, or a sum is given back which varies every year in amount, what figure is to be returned? No single colnmn will give even an approximate idea of the value. Some figure must be set down; the figure chosen is generally the ratable value of 
the land, though possibly a third of the anount has not been realised. Finally, the figures do not in other respects appear to be absolutely reliable. I visitcd five of the parishes incladed in the retarn, and took down from the lips of the incumbents, or have since received in their handwriting, independent acconnts of the very heavy losses which they had snstained and were still sustaining in the period covered by the official retarn. In two out of the five parishes the official return did not disclose the facts which had been made known to me. Probably the incumbents, weary of making returns, repeated as the net value in 1886 the net value of six years before. I also compared a large number of returns which I had obtained personally with those made to Croclfford's Directory for 1885. In seventeen cases the printed returns gave no hint of losses which, as compared with the income of 1874 , ranged from 30 to 70 per cent. Probably some of the printed retnrns may have been corrected in the Directory for 1886 . But they were equally misleading when they were made in 1885. Doubtless to furnish returns is not the most important duty of clergymen, even in the case of publications which are recognised as semi-official statements of the endowments of the Church. Yet reticence seems here to be carried beyond the limits of prudence. Even land-hunger might be sated by a feast npon facts. The other day I read in a pamphlet published by the Liberation Society that it was notorious that the returns made by the clergy of the value of their benefices were 25 per cent. belonv their real value. It is impossible to rebut the charge by appealing to the accuracy of Crockford's Directory; and practical men might say that the accusation served the clergy right.

Many of the examples which I now proceed to give are extreme instances of the effects of agricultaral depression. I do not wish it to be supposed that the condition of the glebeowners is universally so disastrous. Some of the cases show a reduction in rental of from 80 to 90 per cent.; others show a loss, not only of the entire rental, bat of private capital besides. The cases cited of losses sustained from inability to find tenants fairly represent general results. But the effect of agricultural depression is less uniform where tenants have been obtained. So far as I have been able to judge the actnal depreciation in the average rental of glebe livings between 1874 and 1886 varies from 33 per cent. to 50 per cent., or between one-third and a half. Taking the glebes which are thrown on the hands of their owners with those which have been let at redaced rentals, the depreciation may be estimated at between a half and two-thirds upon the previons rentals. But, as $I$ have before said, the mere reduction of the rental does not at all represent the actual loss sustained. 
In many instances glebeowners have been compelled to take their farms into their own hands, either from inability to let their farms, or from the rapid impoverishment of the land by ruined tenants. In such cases glebeowners bave lost heavily. (1) The annual value of a benefice, calculated upon an arerage of six years ending in 1S78, was 502l. 5s. 9d. For the six years ending in 1885 the following were the receipts:-

For allotments, orchard, rent of small fields, fees, tithe rent-charge, \&c.

Receipts from farm $£ 680 \quad 5 \circ 8$

Taluation of stock, tenant right, \&c. $\begin{array}{lll}1,661 & 13 \quad 10\end{array}$

$\begin{array}{rlrr} & £ 7,628 & 6 & 2\end{array}$ Total expended upon farm in six years $\ldots \ldots \ldots \ldots \ldots \ldots \ldots \ldots \ldots$ Balance $£ 453 \quad 4 \quad 8$

Average income for the last six years $£ 7510 \quad 9$

The glebe farm was valued as if it were an ordinary farm; but no incumbent can claim tenant-right in unexhausted improre. ments; therefore the total profits must be reduced by the item included in the valuation for tenant-right. (2) The glebe lands of a second benefice consisted of 250 acres of good " red" land; 105 acres are pasture, and 145 arable. In 1874 the land, which is described as "some of the best in the county," and lies con. veniently close to two railway stations, was let in two farms at a rent of $2 l$. an acre. In 1881 both farms fell vacant. The incumbent, at a cost of $1,500 l$, drained the land, repaired the farm bnildings, reroofed barns, and built sheds. Everything was done to put the land in a letable condition. But since 1881 the farms have been unlet; no reasonable offer has been received. Consequently the glebe is farmed by the incumbent at an annual loss which this year will probably amount to $200 l$. (3) The average net income of a third benefice, calculated on the seven years ending in Christmas, 1879, was 1,005l., deducting landlord's rates, \&c., only. The income was derived from a glebe of 700 acres, consisting in about equal proportions of good red land, inferior red land, and poor cold land. In 1882 the whole of the glebe, with the exception of about 30 acres let in allotments, was thrown on the parson's hands in an imporerished condition. From 1882 to 1885 inclusive he cleared expenses, but made nothing for rent. In 1886 he knows that his income will be "nil"; possibly his books will show a loss of from 100l. to 200l. Daring the period 1882 to $1886,5,650 l$. have been expended in working the glebe. (4) The balance-sheet of a fourth glebeowner shows the following results. The acreage of the glebe is 235 acres, with a considerable proportion of stiff heavy clay. It is farmed by the incumbent, who took to the land in a very foul and exhansted condition. He has a good bailiff working nnder his supervision. 
He has sunk a considerable sum of money in improrements, althongh neither he nor his representatives can make any claim for tenant-right. For the year 188.j the profits amounted to 14l. 6s. 6d. But if the rent is placed on the debit side (250l.), the accounts show a loss for the year of $235 l$. 13s. 6d. (5) In a fifth case the glebe consisted of 130 acres of useful land, within a ring fence, and advantageously situated. The land was robbed by two successive tenants, and finally thrown npon the parson's hands in an exhausted condition. The glebeowner is a man of considerable experience in high-class farming. But the times lave been too much for him. He has sunk 1,000l. of private capital; he has received no interest upon the principal, and he has no security, as has been pointed out, for his investment; he has of course received no rent. This year, after six years' work, the acconnts for the first time meet-without rent or interest (careful accounts have been kept). The best stock has been bred on the farm; the best labourers are employed, and interested in their work by a modified system of co-operative farming. The glebeowner has failed to farm with profit because the land had to be reclaimed from the deplorable condition in which it was left at a heavy expense and in the midst of falling prices. These instances might be multiplied. They afford a fair sample of the results where incumbents have been compelled to farm their glebe-lands for themselves. Probably scarcely one has farmed arable land at a profit in 1886 ; the yield of corn is bad, and the prices of cereal produce low; cattle of all sorts are making poor prices; and sheep alone give the farmer an absolute profit. Without private means it is obvious that, in the last four instances, which are samples drawn almost at random from a host of examples, incumbents could not afford the lnxury of parochial duties; not only would they be nuable to meet the heary calls which are made on clerical incomes, but they would literally and without metaphor starve.

The alternatives to farming at almost certain loss are to accept any offer that is made for the land, or, if it is impossible to let the glebe, to allow it to fall out of cultivation. In one case the timely expenditare of private capital has saved the land. A glebe farm consisted of 500 acres of strong land, requiring careful drainage and attention. In good years it had been let at a rental of 1,000l. a year. In 1880 the present glebeowner found the land in a very neglected condition. Of the 500 acres, 360 rere grass, forty-five arable, fifty nominally arable, but really nncultivated, and a mass of twitch and weed. Forty-five acres were laid ont in allotments, two-thirds of which were ont of cultivation. The present incumbent was fortunately a man of practical experience, possessed of private means, and accnstomed to the management of land. 
He has seeded down abont sixty acres of his arable land, and now only thirty acres out of 500 are arable. Ten acres are laid out in allotments, and forty acres are kept in hand, which conld be let without dificulty at $30 \mathrm{~s}$. an acre. With the exception of these forty acres all his land is let. Two farms consist of 130 and 120 acres respectively; the remaining eight are let in small holdings of from fifty-six to four acres. The incumbent has expended 1,500l. on the improvement of the glebe. The rent of 460 acres is $600 l$. in 1886, not connting $60 l$, the estimated rental of the land, in hand. Upon the old rental there is a loss of $310 l$. a year. But there can be no donbt that, had the incumbent not been a man possessed of experience and capital, the loss would have been infinitely greater. "It is almost certain," said the glebeowner, "that unless I had been in a position to make this outlay the glebe would have become comparatively valneless."

In many instances the rental of glebe farms has dwindled almost to nothing. Those who have obtained tenants are scarcely better off in point of income than those whose land is unlet. (1) A benefice consisted of 123 acres of glebe, 10 pasture, the rest arable. In 1875 the rent was 220l. a year. For the seven years ending in 1885 the average income of the clergyman was $45 \mathrm{l}$. gross, or, deducting a charge to Queen Anne's Bounty, 25l. (2) A second living was, in 1880, of the net value of $445 l$. The income was derived from a glebe of 283 acres. Now, in 1856, the net valne of the living, after dedncting rates and taxes, tenths, and a charge to Queen Anne's Bonnty for the repair of the chaucel and for farm buildings, is $28 l$. a year. (3) $A$ third clerical income is derived from the rent of 240 acres, chiefly arable, let in two farms and eight acres laid out in allotments. In 1880 the land was let at an average rental of $32 \mathrm{~s}$. an acre. For three years the two farms were thrown on the parson's hands. During that period he had, at past seventy, to tarn farmer and caltivate the land himself. Not only did he lose the rent but nearly 1,000l. of private capital. Now, in 1886, the land is let at 15s. an acre. But the glebe is now charged with an annual sum for principal and interest on a loan raised for drainage purposes of 22. .; and this year the incumbent was obliged to give back to one of his tenants $27 l$. 10s. Thus the living which in 1880 was worth $384 l$. has now dropped to $180 l$. - 22l.$27 l .10 \mathrm{~s}=130 \mathrm{l}$. 10s. (t) In a fourth case the income of a family living in private patronage is derived from a glebe of 474 acres of strong wheat-growing land which is now compara. tively worthless. A thonsand pounds has been expended within the last twelve years npon the improvement of the glebe. In 1874 the gross rental was $905 l$. and the net ralne $641 l$. In 1886 the gross rental was $364 l$. and the net value $130 l$. (5) In a fifth case 328 acres of glebe land was formerly let at a rent of 
$508 l$; the average rental for the last three years was $188 l$. On this glebe the incumnbet has expended $800 l$. of private money. (6) Another benefice consisted of 411 acres of glebe land. The former rental was $578 l .10 \mathrm{~s}$. The present rental received is only $179 l$. ; the ratable value of the land is $240 l$., but it has not been realised. If the incumbent were asked to make a return of the value of this benefice he would probably return it at the ratable value for the vacant land plus the rent actually received for the land occupied by tenants. But the result would obviously be misleading. The living, it may be added, is charged with the annual payment of $158 \mathrm{l} .10 \mathrm{~s}$. Thus the rent actually received covers the annual charge and leaves a margin of $20 l .10 \mathrm{~s}$. (7) The gross annual valne of a benefice consisting of 589 acres formerly realised 1,100l. a year. In 1886 the rental has fallen to $771 l$. The net value of the living now amounts only to $274 \mathrm{l}$. More than 3,500l. has been invested in the improvement of the land from private sources, if that can be called an investment, which pays little or no interest and offers no security for the principal. (8) Another living consists of 150 acres formerly let at $318 l$. The farm is now vacant, and it is offered at $25 \mathrm{~s}$. an acre. If this rent could be obtained, it would show a reduction of $130 l$. The living is subject to a charge to Queen Anne's Bounty of 64l. a year.

These instances will snffice to illustrate the terrible depreciation in the value of glebe livings which has resulted from prolonged agricultural depression. Some glebeowners have escaped the full effect of the storm, becanse their land is accom. modation land or possesses a sporting value, and thus the old rental has been maintained. Others, again, have not suffered in proportion to their neighbours because a part of the income of their benefice consists of tithe rent-charge, or has been augmented by the proceeds of sales of land to railways, or of wayleaves over the glebe granted to ironstone companies. Bnt where an incumbent is solely dependent for his income on the rental or the produce of glebe farms, and where the land is heavy and possesses no exceptional value which raises it out of the category of purely agricultural districts, his position is one of disaster if not of ruin. He has felt in an acute form the pinch of poverty. He lives without servants, without fires, without books, and on the food of an ordinary labourer. The per-centage of the loss sustained by glebeowners exceeds that of ordinary landowners, and as a rule they have less to fall back upon and are less able to afford the diminution of income. Any practical man who considers the peculiar disadvantages under which incumbents labour in the management of their land would expect their losses to be exceptionally severe. The blow was unexpected; found glebeowners wholly unequipped for the coming struggle 
their land was ill-drained, inadequately provided with farm buildings, and so highly rented and held on so insecnre a tenure that it attracted only the worst class of farmers. From ignorance of agricultural matters the clergy are generally bad landlords. Even when incumbents are well versed in rural affairs, the uncertainty of their interest in the land not only deprives them of the best stamp of tenants, but robs them of the ordinary inducements which stimnlate landlords to improve their estates. An incumbent enjoys only a life interest in his glebe; he does not know or care for his successor; he does not do his duty by his family if he makes a large ontlay of private capital upon land which passes at his death to strangers. He has not even the ordinary incentives or the moderate security of tenant-farmers; he is under no obligation to farm the glebe in a husband-like manner; neither he nor his representatives are entitled to claim compensation for nnexhansted improvements. It is frequently said that glebes are a standing reproach for their bad farming to the rural economy of the conntry. If the charge is true, a considerable part of the blame attaches to the Legislature. This portion of the subject I reserve for my final letter, when I shall venture to suggest some legal changes in the position of glebeowners, which may assist them to hold their own with ordinary landlords. 


\section{IV.-THE RELIEF OF THE TITHEOWNER.}

Tithe rent-charges and glebe lands are assailed from many different points. Objections may be urged against the first which do not apply to the second. Yet both forms of property may be attacked on the common ground of religion and of agriculture. One group of assailants rallies round the banner of Disestablishment and Disendorment. One division of this party, waiving the question of property which is involved, arges that parochial endowments are public property in the same absolute sense as the produce of the taxes; the other asserts, without any violation of legal principles, that all property devoted to the maintenance of religion may be, and ought to be, appropriated by the nation, because the purpose to which it is dedicated is obsolete, if not mischievous. Either section of this party would be content to preserve tithe rent-charges, and to apply their proceeds to secular objects. With this side of the attack I do not propose to deal.

The second point of view from which glebe lands and tithe rent-charges are assailed is that of the agriculturist. In the interests of farming the only objection to the tithe rent-charge is not its object, but its existence. It is said that the tithe rent-charger is a sleeping partner, and the glebeowner a hybrid landlord who is over-indulgent to bad tenants and rarely helps those who are disposed to improve their holdings; neither is, in fact, in a position to do his duty by the land. This charge is in the main true. On general grounds it is eminently desirable that the land should be freed from all fixed charges, so that its use and occupation may be absolutely free and unrestricted. Similarly it is essential that owners and occupiers of land should enjoy ample security for their outlay of capital, and should feel the strongest indncements to develop to the utmost the resources of the soil. Agriculture demands the removal, as far as possible, of fixed charges secured upon land, and the general substitution of fall ownership for limited life-interests.

Both the temporal and spiritual interests of the clergy seem to demand that their incomes should be derived from another source than land; a revenue derived from land is at the present day neither dignified nor secure. A fluctuating, uncertain income, greatly diminished by the expenses of collection, subject to large deductions for bad debts, extracted after long delays, and often at the cost of bitter irritation, from the pockets of distressed parishioners is in many respects a less desirable revenue than a stipend smaller in amount but prnctually paid, a stipend 
which is subjected to no delays, difficulties, or expenses of collection, a stipend which never fluctuates or remains in abeyance. Ask the parochial clergy-whether the tithe rent-chargers of Wales and Essex, or the glebe-owners of the midland conntieswhich they would prefer, and you would receive but one answer.

The higher interests of the Church seem to me to point in the same direction. It is desirable that clerical incomes should be disengaged from the land, not only because the possession of land by the few always awakens envy in the less fortunate many, which militates against the acquisition by the clergy of moral influence; nor is it desirable merely because agriculturists as well as clergymen have pecnniary reasons for complaining of the existing state of things. The presence of a resident landlord, like the clerical tithe or glebe owner, in every parish is a public advantage which cannot be ignored; but whatever be the form assumed by parochial endowments, severance from the land, not removal from the parish, is contemplated. The question, thus limited, must be determined on wider grouds. Agriculture is a matter of national interest; the welfare of a people in a large measure depends ppon its prosperity. It is important that the land should produce the largest possible quantity of food, and employ the largest possiblo amount of labonr. It is still more essential to give every reasonable facility to the free development of the labouring classes which are engaged in the cultivation of the soil. If the connection of the clergy with the land limits its prodnctiveness and hinders its social utility, the position which the Church occupies is one of antagonism to the interests of the nation.

If any change is contemplated in the existing relations of the clergy to the land, one thing is imperatively necessary in the interests of the Church and of the nation, as well as of the classes more directly interested. If nsefn] work is to be done the general policy must be from the first determined. Parliament ought to be prepared with its final answer to the questions whether the land is ultimately to be freed from tithe rent. charge, or whethor such limited ownerships as those of glcbeowners are to be continued. Until these questions are answered every patch which is put in the existing system will only make the rent worse. We have already had an illustration of the uselessness of tinkering at reforms; the Extraordinary Tithe Act will not hold water, hat is already found to require further alteration. The same Act also affords a waruing of the manner in which the interests of the clergy may be whittled away in a series of compromises in which they always occupy the position of the weaker party. So long as legislation drifts aimlessly on, blown lither and thither by the capricious 
gusts of the popularis aura, we may contemplate as certain the accumulation of a mass of useless Acts, no sooner framed than they are amended, modified, or repealed, which will involve the whole question in an intricate knot that only the knife can disentangle. In whose hand is that weapon likely to be placed? Will passion or reason guide the stroke? If, on the other hasd, the policy is settled, changes may be made gradually and with mature consideration. Nor will the Church or the conntry really suffer from delay. Less loss will be inflicted by the maintenance, in all its details, of the existing system than would inevitably result from hasty, ill-considered legislation. Some immediate relief may be administered to distress; many of the agricultural and clerical objections to tithe rent-charges or glebe lands as they exist are capable of removal, or, at least, of large diminution.

In this letter I propose to deal with tithe rent-charges, and in my next, and last, with glebe lands. In each of them I shall offer some suggestions on the two questions which arise on both divisions of the subject-(a) What immediate changes are desirable or practicable? (b) What onght to be the ultimate goal towards which legislation should be directed?

As I previously pointed out, landowners have profited largely at the expense of titheowners. They have derived considerable benefit both directly and indirectly from the Tithe Commntation Act of 1836. Every invention which increases or cheapens production diminishes the amonnt of the charge; they are able to develop to the full the resources of the soil withont considering the increased tax of the tithe; they have gained, and rightly gained, the whole increment which has within the last half-century resulted from agricultural progress. In all these respects, as well as many others, the Tithe Act bas worked fairly and has promoted agriculture. But when the titheowner gave $\mathrm{np}$ his claim to share in the increased profits of the land what was his quid pro quo? He took a fixed rent-charge instead of a tenth of the produce, on the understanding that he would be relieved from the odium and nnpopularity which his existing relations with the occnpiers necessarily produced. The contract has been performed on the one side, for the landowner has been enriched at the expense of the titheowner; it has not been performed on the other, for the titheowner is still placed in the unpleasant relation towards the occnpier from which the Legislature intended that he should be relieved. How has this one-sided result been prodnced? By an arrangement between the landowner and the occnpier, eutered into for their mutual advantage withont the consent of the titheowner, often against his will, and always against his interest. Yet this arrangement between landlord and tenant 
persevered in throughout prosperous seasons, is now made the excnse to bring pressure to bear upon the titheowner to waive his legal rights. A correspondent of a leading London daily paper warns the clergy against swelling the cry that the rent-charge should be levied upon the landlords, lest that class be turned from friends into foes. Every one is aware that landed interests have suffered heavily by agricaltural depression; and the clergy, who have in conntless instances received sympathy, aid, and encouragement from their squires, are probably the last people who would wish to add to the burdens of landlords. But if landowners have all along paid the tithe, if they have only used farmers as the transmitters of their money, there can be no additional burden in the resumption by the real paymaster of his legal obligation. Many landlords have already accepted the daty, which has always remained theirs, of paying the tithe themselves directly. Higher interests are at stake than those of money. The continuance of the present arrangement imperils the stability of the Church as well as of the fundamental principles of property. Compnlsion is an ugly word; but, if landowners will not voluntarily accept their legal position, they must be compelled to do so.

It is, I think, plain that the tithe rent-charge mast be paid by landlords not mediately, but in the first instance. It is a fluctnating payment dependent on septennial averages. If the average was triennial, as has been proposed by the Essex Chamber of Agriculture, or even if it was computed annually, the aggregate payment in a series of years is necessarily the same. The landowner is a permanent holder of land; the farmer a temporary occupier. It does not concern the permanent holder whether the tithe rent-charge is calculated on a septennial or triennial average, or eren whether it is annnally computed; to him it will be the same thing in the long ran. Bnt the incidence of a septennial average may affect temporary occnpiers injuriously. If the payment of the tithe is resumed by the landlord, nothing need be said respecting the redemption of small tithes in towns; they will be paid in a lump sum by the landlord instead of being collected in driblets with great diffi. culty and at considerable expense from a number of small struggling occupiers. For the same reason the various suggestions for fixing a new period for the average need scarcely be considered. Many high agricultural authorities urge that the charge should vary with the prices of each year. The present state of foreign politics seems to render snch a change detrimental to the interests both of titheowner and tithepayer. War would raise prices rapidly and largely; they wonld fluctuate quickly. Not only would the titheowner's income be unsettled, but 
the sudden rise and fall wonld introduce a gambling element into farming which would be altogether disastrous. The experience of agriculturists in the first twenty years of the present century condemns any such change by its appalling record of ruin and bankruptcy.

So far, then, the only change proposed is that tithe should be paid directly by the landlord. The result of the proposed change will be advantageous to both the clergy and the landlords, who are really the only parties concerned in the question. The clergy will be at length relieved from the false position in which they are placed towards the tenant farmer, and a frnitful source of misconception and hostility will be checked at the spring. The landlord will be in a better position to judge of the length of tether which he can safely allow to his tenant. At the present moment parsons can distrain for two years' arrear of tithe, and their claim is a first charge npon the land. Many landlords, if the occasion arose, would be nnpleasantly surprised by finding that the farm produce on which they calculate as security for rent is subject in the first instance to the parson's clain for two years' arrears of tithe. Again, landlords will be better able to calculate what remissions of rent they may reasonably grant. At the present moment a farmer can play off landlord against parson, demand reductions from the one because lie has to make a payment to the other, and often obtain abatements from both.

The shape which the present agitation has assumed is the demand for a recommutation of the tithe rent-charge. Here, again, the bargain made between landlords and tenants for their mutual advantage has plainly inspired the cry. But in any discussion of the principles of the Commutation Act of 1836 it must be borne in mind that that arrangement ras sanctioncd by the Legislature, that it is confirmed by reiterated Acts of Parliament, supported by hundreds of legal decisions, acted upon in innumerable sales and transfers of land, ratified by every purchase of tithe rent-charges, strengthened by repeated and undisputed acts of ownership. In all dealings with land for the last half-century the bargain made in 1836 has been regarded as permanent. Round it have grown up the vested interests and the reasonable expectations of fifty years. Changes cannot be lightly made in the terms of a bargain, thus made and ratified, solely on the ground that it is disadvantageous to a class which is not one of the parties to the original contract, nor eren concerned in its present effect. To transfer the payment of tithes from tenants to landlords will postpone the question which is ultimately at issue; it will not bring about a final settlement. Similarly, any readjustment of the arerages can only prore a temporary expedient. It is alleged that the present mode of calculating the arerages 
is aufair because no account is taken of inferior wheat, which does not come into the market, bat is consumed by stock, or because the average is kept abnormally high owing to the excess of barley and oats over wheat, upon which it is calcnlated. Other objections may be urged against the principle adopted in 1836, which are more or less true and weighty. But as between titheowner and landowner, it is confidently snbmitted that these questions are immaterial. Existing landowners have, with few exceptions, acqnired or inherited their property subject to the arrangement then made: the bargain struck between the two parties has greatly benefited the tithepayer; many of the considerations which agitators seek to introduce into a new arrangement would, if entertained in 1836, have operated to the disadvantage of the landowner. If it can be proved that the prices of corn on which the arerages are calculated inclnde railway and loading dues, a case is shown for change; this artificial increase in price was never contemplated in the original bargain. Bat, except in this instance, there does not exist, in my opinion, any ground for the demand for recommutation.

The agitatiou which the landlords' arrangement has fostered will be used to pare down the interests of the clergy; when this has been effected by a recommutation the agitation will reconimence; the first step in legislation will shortly be followed by a nother Act compelling landlords to redeem the diminished charge. On the other hand, it is possible that the present agita. tion against tithe is artificial, and that if the payment is transferred from the tenant to the landlord it would gradually disappear. So, again, it is possible that the future will not be so bad as the present. On these points there may be wide discrepancies of opinion: I can only state my own conviction that nothing short of a complete redemption of the tithe will ever permanently settle the questions which tithe rent-charge has always raised.

The issue really is whether the tithe rent-charge, which is, in fact, a first mortgage on the land on which it is payable, should be permanently redeemd once and for all. There can, I think, be no dispnte that the removal of this fixed money payment secured upon the land is demanded in the interests of agricnlture: No doubt agricultare prospers best when capital is free. The argument equally applies to the land-tax or any other form of charge secured upon land. Some of my readers may be familiar with Carleton's Farm Ballads; if so, they will remember "The Mortgage: "-

"We worked through spring and winter, through summer and through fall,

But the mortgage worked the hardest and steadiest of them all;

It worked on nights and Sundays, it worked each holiday;

It settled down amongst us and it never went away. 
Whatever we kept from it seemed almost as theft;

It watched us every miuute and it ruled us right and left.

The rust and blight were with us sometimes and sometimes not;

The dark-browed, scowling mortgage was for ever on the spot.

The weevil and the cutworm, they went as well as came;

The mortgage stayed for ever, eating hearty all the same.

It nailed up every window, stood guard at every door;

And happiness and sunshine made their home with us no more.

Worm or beetle, drought or tempest, on a farmer's land may fall;

But for first-class ruination, trust a mortgage 'gainst them all."

Ailowing for some poetic exaggeration, these verses express the paralysing effect npon farming of fixed charges upon land. A mortgage produces the same effect in England as $\mathrm{Mr}^{\mathrm{r}}$. Carleton found that it worked in America. It must be remembered that tithes are not more an obstacle to agriculture than any other form of mortgage; yet, though tithe rentcharges differ in no material respect from the land-tax, and though neither are properly a charge upon tenant farmers, the latter have conceived a widespread, deep-rooted, and ineradic. able objection to tithe rent-charge. Looking to the tendencies of modern legislation, will any shifting of the incidence of the charge diminish its unpopularity? Will it be possible to convince tenant farmers that the charge does not raise rents, or labourers that it does not lower wages? I venture to think that, in some form or other, the redemption of the tithe rent-charge is, sooner later, inevitable. On the details of any proposal there must necessarily be great differences of opinion. Titheowners and tithepayers are not likely to agree offhand upon the number of years' purchase, or the compulsory nature of the clauses.

By far the best and most equitable scheme for the redemption of the tithe rent-charge is that put forward by Mr. Ryde, past president of the Surveyors' Institution. It will be fonnd in the Trans. actions of the Society, Vol. XIX., partiii., pp. 57 to 95. He assumes that the average "price of corn for any seven years in the future will not approximate more closely to the average price of the years 1828 to 1835 , apon which the rent-charge was originally based, than 90 per cent." He proposes to redeem the whole rentcharge at this figure. In other words, the sum with which he deals is at par value $4,000,000 \mathrm{l}$; but it is reduced by 10 per cent. to represent the present fall in the averages, and $15 \mathrm{per}$ cent. for the cost of collection and rutes and taxes to $3,000,000 l$. Three-fiftlis of this sum is owned by parochial incumbents, the remaining two-fifths being in the hands of impropriators. The whole of this sum of $3,000,000 l$. is to be compulsorily redeemed by the landowners "at twenty years" pnrchase, or $60,000,000 \mathrm{l}$.; but it is proposed to borrow the sum of $75,000,000 l$. (being the amount of twenty-five jears' parchase)." The balance of $15,000,000 l$. is to go to augment the purchase money of parochial tithes to twenty-eight and a half years' purchase. 
The result to the clerical titheowner will be a net and certain income, paid quarterly, of $86 \mathrm{l}$. a year, in licu of his present nncertain income of 100l. a year. Mr. Ryde relies on the camulative power of money at compound interest when regularly invested by annual payments to recoup the principal in forty. seven years. At the end of that period-

"We shall have not only the land made of the ralue which land and tithe rent-charge together now possess, but we shall have in addition to that 75 millions of pounds sterling created by the thrift enforced by the Redemption Act."

The scheme is one which deserves carefal attention.

Mr. Ryde's plan is, of course, open to objections. It may be said, for instance, that the redemption at 90 per cent. is unfair. No doubt the average value of the charge since 1836 has been 3 per cent. above par. But it is obvious that the average of the next seven years, unless a great war should in the interval temporarily raise prices, will witness a reduction even upon the 90 per cent. of 18s6. Nor is it likely that the present generation will witness any material rise in the price of corn. The fall resources of India are yet nndeveloped; bat already she can throw vast quantities of corn upon the home market at prices which defy English competition. A formidable objection was suggested to me by Mr. Smith Woolley, another past President of the Surveyors' Institution, that the scheme, if carried into effect, will make the clergy Government stipendiaries. But it is submitted that this objection is more formidable in theory than in fact. The clergy are already represented as salaried servants of the State, and, though the statement is absolutely erroneons, it is largely credited; also no relation into which the clergy are brought with the Government is so cletrimental to their interests as their present dependence u pon poverty-stricken parishioners. Another objection is that it is hard to compel landlords, whose land is their ruin, to bny up a further interest in land. Men are often compelled to sell in the interests of the public; have they ever before been compelled to buy? Land. lords may urge that it wonld be equally just to compel the titheowners to bay out the landowners; no doubt numbers would be glad to sell. On this point it is only fair to say that Mr. Ryde's scheme holds out large advantages to the landlords which would begin to accrue from the moment that the scheme of redemption is set in operation :-

"It will," says Mr. Ryde, "place it out of the power either of the titheowner or the landowner to object to the price paid for the rent-charge if the same rate of interest which is represented by the purchasc-money is charged to the landlord for the loan. For instance, supposing the price to be paid for a rent-charge of $100 l$. a year to be twenty years' purchase, or $2,000 l$., it is proposed to charge the landowner during the continuance of the loan 5 per cent.-that is, $100 l$. a year-interest upon the 
principal. The landowner will pay $100 l$, a year interest instead of 100l. a year rent-charge, for a period not exceeding fifty years, after which time there will be nothing to pay. He will derive an immediate benefit from the fact that, in lieu of a fluctuating rentcharge, he will have a fixed and terminable one. He will have acquired the exchange upon a 5 per cent. calculation, whereas, eventually, it will become to him a 3 per cent. property. That will be accomplished in this way. In any estimate of the salable value of his land the amount of net rent is that which is capitalised. A farm worth, say, $600 l$. a year, but subject to $100 l$. a year tithe rentcharge, is only of the value of $500 l$. a year net. This at thirty years' purchase is $15,000 l$. When the title rent-charge is removed the net value will be $600 l$. a year, and the capital value $18,000 l$. The increase in value being $3,000 l$., the price which it is proposed to charge for this increase is 2,000l. There is, therefore, a gain to the landowner of $1,000 l$. in capital value without any payment for it. That is not the only gain which the landowner will make. His land will daily become more valuable as time passes by. The value of the land will continue to increase in anticipation of its being freed from the rent-charge, and after a few years have passed away that increase will become very material."

If the tithe rent-charge is to be redeemed, the financial arrangements of Mr. Ryde's scheme appear to be admirably worked ont. By co-operation between the Government and the landowner it is plain that the titheowner's interests could be equitably adjusted, the land relieved from the burden of the rent-charge, a vexed question permanently solved, and a great increase made to the agricultural capital of the country by the compulsory thrift which the scheme entails. It may be asked, Why distinguish between parochial and impropriated tithes? Why pay for the former twenty-eight and a half years' purchase and for the latter only twenty jears' purchase? The reasons are sufficiently obvious. The clergy as a body carn their tithes, except in the opinion of those who are opposed to the maintenance of any religion whatever. Again, the tithe rent-charge represents gifts to the parochial clergy or to monastic and conventual eatablishments; it represents an endowment for spiritual ministrations as well as an endowment for what may be called State purposes of education, maintenance of panpers, \&c. The first endowment was given to the parish priest, the second to the monk and nun. Parochial tithes rere given to the parish clergy to perform divine service, to practise hospitality, to instruct the people in religion by precept and example. They werc never given to the poor, unconth, nnlearned parish priest to vie with the regular clergy in the maintenance of schools, workhouses, asylums, penitentiaries. On the other hand, it is incontrovertible that monastic endow. ments, now partially represented by tithe rent-charge in the hands of impropriators, were partly bestowed for these objects. In the case of the parochial clergy the will of the "pious 
founder" is still carried ont, if not verbally, at least in close accordance with the "cy prìs" doctrine; bat in the case of the lay impropriators the original purpose of the tithe is wholly disregarded. This difference in origin and in application is not urged in defence of anti-tithe agitation. On every existing principle of the law of property tithe rent-charges seem to me inviolable. Bnt I only insist upon the difference in order to explain the distinction drawn between tithes in the hands of the clergy and tithes in the hands of laymen. 


\section{V.-THE RELIEF OF THE GLEBEOIVNER.}

Agricultural distress has fallen upon the grlebeowners with exceptional sererity. The extraordinary losses which they hare experienced are not due to any inferiority of their land. The parcels of which their glebes are composed are often extremely scattered; they are generally situated at an inconrenient distance from the village. Bat in quality the soil is often some of the best in the parish. When the Enclosure Acts were passed the heary lands, which before the general introduction of roots and before the recent agricultnral depression were most highly ralued, rarely fell to the lot of the parson. He was apportioned the lighter lands which fringed the edge of the common field. The parson in fact got the rind of the cheese. Bnt the rind is now worth more than the inside; it is only the light lands that make the rent. Distance and want of compactness are thus compensated by the character of the soil. How, then, are the exceptional losses of glebeowners to be explained? Becanse glebeowners have been placed at a great disadrantage in the management of their land, personally, professionally, and legally.

The clergyman is generally ignorant of rural matters. The son of a country squire may be hopelessly plucked for the Arms or his "Little-go ;" but when he succeeds to his estate he knows something of the management of landed property; he has imbibed his knowledge as it were with his mother's milk. The parson, on the other hand, may be a brilliant scholar, or a profound theologian; but he knows nothing of farming or of farmers. When he is called to the management of landed property he refreshes his memory with the Georgics, perhaps heares a gentle sigh of regret that he had studied the "De Officiis" instead of the "De Re Rusticâ," and enters with a light heart on a difficult profession in which science without practice is a frequent canse of rain. He soon finds that he must buy his experience, and the necessity comes upon him at an age and under circumstances when he can ill afford so expensire a purchase. Very often he is as nnreason. able as he is ignorant. Accustomed to be infallible in the pulpit, he forgets that he may blunder in the farmyard. He is generally too poor a man to meet energetic tenants half-way in improrements. Even if he has the means he neither possesses the requisite knowledge nor feels the ordinary stimulus to lay ont money upon the land. He does not know when to extend a helping hand, or when to give a notice to quit; he lets one 
tenant run too long; he pulls up another too short. Uneasily conscious that his knowledge is limited, he mistakes suspicion for caution; he is parsimonious where he should be generous, a spendthrift when he ought to be a miser. He is not in the same position as an ordinary landlord. His children cannot inherit the glebe lands. Not only is he a life tenant, but he does not know his successor. His duty to his family prevents him from laying out private capital to benefit a stranger.

The personal disadvantages of glebeowners are increased by professional and legal difficnlties. I have already spoken of the dilemma on which glebeowners are perpetnally impaled, and the risk which they always rnn of losing their income or their popularity, or both. He is disinclined to be strict in enforcing agreements lest he should quarrel with his parishioners; at the same time he cannot afford the risk of having his land unlet. But in other ways the clergyman is prohibited by his profession from fair competition with lay farmers. If he farms himself he is forbidden by law to bny or sell in public markets. At a sale of stock he cannot pnnch a beast in the ribs with his own clerical fist; samples of wheat or barley must not be drawn from the clerical pocket. On every sale or purchase he has practically to pay commission. If he buys, he must make his bargain by deputy, and the bailiff is known as the parson's man; if he sells, the auctioneer puts up his stock as the parson's beasts. He is less well served by his men. The master's eye is more than ever necessary in farming. In some districts, for instance, of Northants the able-bodied men have been drafted into the iron-stone works; those who remain are idle, lie-abont fellows, who only work by compnlsion. The quality of the agricultaral labourer has universally deteriorated. Everywhere he works less hard, and is less generally useful. The employer is only master on Saturday night. No clergyman can afford the time to be always with his men, and, if he is not, the wages are not earned. If the glebeowner lets his farm he does not attract the best class of tenants. Many farmers deserve every consideration for their honourable efforts to keep their engagements; but to give them a chance of farming successfully they demand a large outlay of capital in buildings, drainage, and improvements. They know that glebeowners are, as a rule, unable to afford the expenditure, and for this and other reasons they do not compete for glebe farms. Consequently parsons are very often compelled to fall back upon inferior tenants. Numbers of farmers merely skin and rob the land by improper cultivation, and then throw up their holdings. Farming to leave has become a profession. A midland county land-agent overheard an altercation between an outgoing and incoming tenant. "Don't tell 
me," said the outgocr, "Low I ought to leave a farm. I've left tive in seven years, so I ought to know something about it." The first victim of these chevaliers of agricaltural indnstry-these so-called farmers who live by their wits-is the parson. Before the yearly tenancy has expired he bitterly regrets his bargain.

When the agricultural depression commenced glebe lands werc often wholly unprovided with farm-buildings, for they had been let to men who farmed them with other lands; they were neglected by tenants who left the glebe without manure, or allowed it to become foul, and robbed the parson to pay the squire; they were ill drained; the rents were screwed up to the head; the amonnt of arable land was out of all proportion in comparison with the scanty pasture; many of the tenants were men of straw, who went down at the first breath of the storm; others who were more substantial men were ruined becanse the glebeowner did not know the exact moment when to assist his tenant or bad not the requisite capital to give a helping hand. For the last twelve years agriculture has been a struggle against odds; what chance has the glebeowner had of improving the position in which the commencement of the depression found him?

The law puts the finishing tonch to the glebeowner's difficulties. But, judging from the report of the committee and the resolntions upon it which were agreed to by the Lower House, Convocation seems to exaggerate the legal impediments by which the glebeowner is encumbered. Convocation holds that no spiritual person "licensed to perform the duties of any ecclesiastical office" may farm more than eighty acres of land withont the consent of the Bishop. The point is of some importance, as in the nidland counties some Archleacons have acted in accordance with the opinion expressed by Convocation. The question turns npon the meaning of 1 and 2 Vict., c. 106, ss. 28-30. The 28th section forbids any spiritnal person, beneficed or performing ecclesiastical duty, "to take to farm for occupation by himself by lease, grant, words, or otherwise for term of life or of years, or at will," above eighty acres of land withont the consent of the Bishop. The words quoted are the governing words of the section. Glebeowners who cultivate their orn glebes, squire parsons who cultivate their own demesnes do not take land to farm nnder a lease, grant, or any other writton or verbal contract; they do not occapy their own lands as tenants for terms of life or years or at will. The section cannot therefore be directed against glcbeowners or squire parsons. What, then, is its meaning? It applies only to the clergy as tenant-farmers; its object is to prevent clergymen from farming on a large scale by forbidding them to rent, as tenants, more than eighty acres of land withont the consent of tho Bishop. The two following 
sections support this construction. Section 29 forbids spiritual persons, inter alia, to bny and sell for profit or gain. Section 30 provides that it shall not be deemed to be illegal trading if spiritual persons bay or sell for gain or profit cattle, $\&$ c., necessary for the occupation, \&c., of any glebe, demesne lands, or other lands or hereditaments which may be lawfully held and occupied by such spiritual person. In other words, so long as spiritual persons do not buy or sell iu person in any market, glebeowners farming their own grlebes, squire parsons cultivating their demesnes, or clergymen who have rented land in compliance with section 28 may buy and sell for profit or gain, so far as is necessary for the proper cultivation of the soil.

In several other legal points I differ with all respect from the opinions expressed by Conrocation. The law with regard to cmblements or way-going crops does not appear to me to be correctly stated. Convocation also doubts whether the severed produce of glebes held in hand, such as corn in stacks or hay in ricks, is the property of a resigning incumbent, or, if the benefice is vacated by death, of the representatives of a deceased incumbent. Nothing short of express rrords in a special statute will, in my opinion, divest incumbents or their representatives of rights of property universally enjosed.

Apart from doubtful points, there are indisputable difficulties which the law has imposed on glebeowners in the snccessful development of their land. The Agricultural Holdings Act, for instance, confers upon one class of tenants security for unexhansted improvements, which is not enjoyed by lifetenants in the pecnliar position of glebeowners. I have described the condition of glebe farms at the commencement of agricultural depression. A bold and rell-timed expenditure of capital apon the land saved many private landlords from rnin : they were jnstified in the ontlay becanse they knew that their families would inherit the benefit of the capital; similar expenditure was eren more urgently needed npon glebe farms; but was the outlay justified when only strangers henefited? $\Lambda$ few years pass, and the principle which would confer npon glebe. owners the required security is granted to ordinary tenants. Tenant farmers are now entitled to compensation for nuexhausted improvements. But the glebeowner can claim nothing from his successor eren for structural improvements. He may have erected at his own private cost furm buildings where none existed before; ont of his private capital he may have built farm-houses and cottages. These buildings may be absolutely necessary; without them the land would fall out of culti. vation. Yet he receires no compensation; probably he or his representatives may be further mulcted for dilapidations upon bnildings which he has giren as a free 
gift to his successor. Still less can the glebeowner obtain compensation for drainage, or for a long course of liberal farming, for bones, chalk, clay, artificial manure, or feeding-stuffs consumed on the holding. 'The Legislature has admitted that the maxim, "Quicquid plantatur solo accedit solo," is absurd in its application to tenants; it compensates the tenant for the additional ralue which his enterprise and capital has bestowed npon his land; it has practically conceded that without this compensation agriculture cannot be successfully practised. Yet for the unfortunate glebeowner the Legislature retains in all its vigour this obsolete maxim; and legislators denounco glebe farms as a standing reproach to English agriculture. It penalises the clergy by an excessive handicap, and sneers because they are last in the race. Shall we apportion the blame? How many of the assailants would have done what the abased class of glebeowners have done? It is no slight proof of the pnblic spirit by which glebeowners have been animated, that they have sunk so much private capital in the land-an ontlay which cannot benefit their children, an outlay for which they have no secnrity, which yields the smallest and most uncertain interest, and which by the operation of the Dilapidation Acts is often the source of farther loss. The majority have straggled, though their loss was certain and immediate, to keep the land going and to restore it to better condition. Another circumstance renders this outlay still more unselfish. In ordinary tenancies there exists an implied contract to caltivate in a husband-like manner. The tenantfarmer is open to a counter-claim on the part of the landlord for a breach of this implied covenant. No such contract exists between an incoming and ontgoing incumbent. If the land is allowed to fall out of cultivation the outgoing incambent incurs no liability to his successor.

While the Agricultnral Holdings Act thus dangles before the eyes of the glebeowner a security which his tenant enjoys, but from which he himself is debarred, the Act has in another respect proved an anmixed evil to the parson. Not only does it refuse to relieve him of the millstone rond his neck, but it hangs a fresh weight thereon. In all contracts with regard to the land it arms the tenant-farmer with a weapon which makes him master of the situation. Suppose a living changes hands. The new incumbent goes to the tenant, and says, "Well, Mr. A., I snppose you will go on on the old terms." "Oh, dear, no," says the farmer, "I want a reduction of so mach per ceut. on my rent, and such and such improvemeuts." "I can't do it," replies the parson. "Very well," retorts the farmer, "then I throw ap, and bring my claim for nnexhausted improvements against you." If tho parson refuses to 
yield to such pressure he pays a heary bill for improvements in which he never benefited; the farm is thrown on his hands; he risks its being unlet. Suppose that he has not obtained a tenant when the former occupier leaves. He has, as landlord, to pay compensation on some of the twenty-three improvements of the Agricultural Holdings Act; he is lucky if he escapes litigation with an opponent who is advised by a speculative attorney and is prepared to go bankrupt if the law decides against him. Against this pressure secs. 29 and 39 of the Agricaltural Holdings Act afford no adeqnate protection or relief. The glebeowner has also to take to the valuations as if he was the incoming tenant. At the end of three or six months he finds a tenant; the latter pooh-poohs the valuation, refuses to take to the fallows which the former tenant set off against his rent, and probably demands to hold the farm for nothing during the first half-year of the tenancy.

Already the long-continued agricultnral depression has made the Act comparatively valueless. It was framed to encourage capitalist farmers who were eager to lay out money on their holdings. Where are they now, and where is their capital? The boon is extended too late. It is like the cheap loaf offered to artisans who cannot earn wages. What will be shortly required is an Act to deal with small, not large farmers, with men who have little money of their own, rather than with capitalists. The probable outcome of the distress will be a large increase of small holdings, and the practical disappearance of the middlesized farm of from 150 to 600 acres. The eye and hand of the master or the capital of the machine-owning farmer will alone overcome the difficulties of existing conditions. If the prophecy proves correct, there is some hope that the position of the glebeowner may be considered; he will no longer stand alone. The Agricultural Holdings Act of 1883 is framed, so far as the glebeowner is concerned, in the expectation that the tenants will effect improrements. On many glebe farms more pastnre is nrgently required. But laying land down to grass is an expensive process; glebe tenants cannot find the money. So again by breaking up middle-sized farms into smaller holdings glebe lands might be let. But here again a large expenditure is required, and the small farmer cannot afford the outlay. In both cases the glebeowner would, I believe, sink his private capital, supposing him to possess it. But if he does, he is absolntely withont any security for his investment. Who can expect poor men to face the risk?

Mnch has been done to remove the stigma of bad farming which rests upon glebe-lands; but much remains to be done. Large sums of money, raised by charges or ont of private capital, have been expended on farms and bnildings, but a considerable 
amount has been wasted throngh the inexperience of the clergy and the operation of the Dilapidation Acts. If the clergy had spent as much on their land as they have on their houses they would be in a better position. Yet in this respect they have only imitated the example of their lay brethren, who have overbuilt themselves in every part of the country. The money is gone; the living is charged with the repayment; it is useless to dwell on what might have been. The Bishops exercised no efficient control over loans from Queen Anne's Bonnty; they have now become more careful. It is eminently desirable that the Bounty-office should imitate the example of the Ecclesiastical Commissioners and send rond an officer to inspect and approve the work which is done. The principal impediments which now exist to the development of glebe lands are the inexperience of glebeowners, the insecure tenure which glebe farms afford to tenants, the want of any security for unexhansted improvements as between outgoing and incoming incumbents.

The inexperience of clergymen in the management of land might be met by the employment of agents. It may be objected that if the land will not support the owner it will not afford a living to the owner and an agent. But I venture to think that in nearly all cases a practical agent would deal more wisely with the land than an inexperienced and often nnreasonable parson. Lawyers are not the best class to whom the management of property can be intrusted; yet it is to country solicitors, if anywhere, that the clergy generally turn. Again, it is not necessary to employ as an agent a man who is so full of work that he only takes a cursory glance at the land with his left thumb in his Bradshaw and his right hand on the rail, and his right foot on the step of his dogcart. What is wanted in each archdeaconry is a sensible, practical, and experienced farmer, who will give both the glebeowner and the tenant sound advice, and who can spare the time to inspect the condition of every part of the glebe at least twice a year. In these hard times it would not be difficult to find farmers of high standing among their brethren who, for a per-centage on the rents, would undertake a practical supervision of the land.

The insecure tenure of glebe farms might be obviated by joining patrons with incumbents as lessors. On the other hand, tenants are in these days shy of taking leases. A lease is too often only a protection to the tenant; it cannot be enforced against them. Yet probably the best tenants of glebe farms were to be found on family livings, where it was supposed that the arrangements of one incumbent would be respected by his snccessor. Undoubtedly insecurity of tenure lowered the class of glebe tenants. At the present moment farmers exaggerate the insecurity in order to obtain reductions of rent. If care 
was taken such a lease as that indicated might meet this difficalty. Some step should be taken in the direction of increased security, for not only in times of prosperity is the objection sure to be revived, but in the present crisis it is repeatedly used against glebeowners.

But the chief obstacle by which glebeowners are impeded is the want of compensation for unexhansted improvements. On the one hand, incoming incumbents should be able to claim against their predecessors compensation for neglect of glebe lands; on the other, outgoers should be able to claim from their successors compensation for unexhausted improvements. The ontgoer should stand towards his successor in the donble relation of a tenant to a landlord and of a landlord to a tenant. He should enjoy the benefits and incur the liabilities of tho Agricultural Holdings Act. At the same time care must be exercised that no improvements are clained which are not absolutely necessary or indisputably useful. For this purpose the assistance of an experienced surveyor is essential; and such an officer might well unite his functions as a check upon extravagance with his duties as a guide to inexperience. Whatever legislation is framed to confer npon incambents secnrity for their unexhansted improvements might well contain clauses clearing ap all doubtful points, such as the right of incumbents to emblements on lands which they hold in their own hands. At the present moment an incumbent who resigns his benefice is not entitled to growing crops, because lie determines his interest in the estate by his own act. The existing law can hardly be considered in a satisfactory state. A Bill dealing with many of these and kindred topics has, I believe, been framed by the Archdeacon of Oakham.

The amount of the loans charged upon clerical residences and glebe lands is very large. The utmost difficulty is experienced in paying the annual premiums out of falling rents. No reasonable objection ean be made to the rate of interest payable to Queen Anne's Bounty. But, in view of the continued depres. sion, it is desirable that the Loans Extensiou Act of 1881, which expired in 1884, should be revived, and power given to throw the repayment of loans over a longer period in order to reduce the amount of the annual instalments. I have already quoted instances in which land improvement companies have foreclosed their mortgages. Two livings have been thns disendowed. The recent Act prohibiting ecclesiastical lands from being charged under certain circumstances with money for improvements does not, of course, affect charges already made. Large tracts of land may, therefore, be sold away from the Church at a heary sacrifice. Can nothing be done to prevent this? A recurrence of this loss can ouly be prevented by a redemption of the loans. 
Resonrces exist which might be atilised for this parpose, especially in the diocese of Peterborough, where the danger is most urgent. Thongh the surface of glebe lands yields no profit the subsoil is often of enormous value. Ironstane exists in large quantities at from $3 \mathrm{ft}$. to $12 \mathrm{ft}$. from the surface. At present this mine of wealth is unworked, owing to conflicts between the Ecclesiastical Commissioners and the patrons of the benefice. It would be easy to raise sufficient money from this source to take up the Land Improvement Charges, and thus to save for the Church the advantage of any prospective improvement in the value of the land. Another fixed charge which hangs like a dead weight round the necks of the clergy, whether glebeowner or titheowner, is the liability incurred nnder the Incumbents' Resignation Act. The gross income of a living derived partly from tithe partly from glebe in 1879 was $759 l$. $6 \mathrm{~s} .9 \mathrm{~d}$. Ont of this a pension was payable to the late incumbent of $245 \mathrm{l}$. In 1886 the gross income has fallen to $597 l .5 \mathrm{~s}$. $10 \mathrm{~d}$; ; but the pension remains the same. The nett value of the living has fallen from $397 l$. $5 \mathrm{~s} .4 \mathrm{~d}$. to 240l.1s. 1d. Thus the pension now exceeds the nett income of the incumbent, who is responsible for the care of the parish, and for whose benefit the endowment is intended. The committee of Convocation recommended that the Incum. bents" Resignation Act should be "amended so as (1) to provide that the charge should not exceed one-third part of the net revenne actually received for any one year; and (2) to secure a reserved minimum for the incumbent who is responsible for the actual daties of the cure." Such a change appears to bs not only expedient but equitable.

The points to which I have alluded by no means exhanst the changes which might be made to mitigate the sufferings of the clergy, and to give them the same chances of developing the resources of the soil that are already enjoyed by the rest of tho community. The question of rates is one upon which $I$ have no time or space to dwell. This is a grievance which the clergy share with all owners and occupiers of land. Bat I take the opportanity of expressing my thanks to the Rev. A. C. Dicker and others for the information upon the subject which they have kindly placed at my disposal. I hope I may be able on some future occasion to turn it to acconnt.

There remains the larger question, What is to be the altimate fate of clerical glebe iands? Are they to remain in the hands of the clergy? Are they to be transferred to the Ecciesiastical Commissioners? or are they to be sold? If the latter course is pursued are patrons to have the right of pre-emption? or is the land to be sold to the highest bidder? With these questions must also be considered the proposal to sell the glebes for allotment parposes. 
I am well aware of the importance of the secular side of the position of the clergy, and of the value of maintaining in each parish an independent landowner. I also recognise the possibility of a steady increase in the value of land. Yet on the whole I think that the interests of the Church, the clergy, and the nation wonld be best served by the disentanglement of clerical incomes from the soil. If this is, for the sake of argument, con. ceded, I propose very briefly to consider the various schemes which have been suggested to effect the change.

The tendency of modern agricultural legislation sets strongly against the accumulation of large properties in single hands. It is still more opposed to the tenure of land by corporations. The proposal to transfer glebe lands to the Ecclesiastical Com. missioners appears to be in fatal conflict to these tendencies. The advantages to the clergy would be great, bat, apart from the expenses and difficulties of management, any scheme which contemplates the accumulation of large estates in the hands of corporations can hardly be considered as practicable.

It would be unjust on the part of the Legislatnre to compel the sale of Charch lands at the present moment. 'The large quantity of land thrown upon the market, the compulsory nature of the sale, the low prices of agricultural produce all combine to render the policy of a forced sale in the highest degree prejudicial to the interests of the Church. If the land is to be sold at all, it must be offered gradually and without compulsion. It is impossible to suppose that the value of land has been permanently reduced; in course of time it will most certainly revive. To sell in a panic is simply financial suicide. There is force in the arguments which are used to obtain for patrons a right of pre-emption; but the object of a sale is to improve the position of the rural clergy. To this consideration it appears to me that the claims of patrons must yield. If a clergyman finds a buyer at a fair price, fixed by a competent valuer, he ought, in my opinion, to be able to convert his land into Consols. Incumbents wonld most easily obtain increased facilities for the sale of glebe lands if they were placed in the position of tenants for life under Lord Cairns's Settled Estates Act. This was in fact the principle of a Bill introduced into the House of Commons in 1885, to which the names of Mr. Courtney and Mr. Ince, Q.C., were appended. The Bill, which proposed inter alia to give increased facilities for the sale of Church lands, was subsequently dropped. But the principle on which it proceeded seems to deserve the support of Churchmen; it has already received the sanction of a committee of Convoca. tion, though additional restrictions on the power of sale were at the same time rightly recommended. 
There remains the proposal to sell glebes for allotment grounds. The scheme betrays some ignorance of the condition of rural parishes. Most parishes are fully provided with allotments; sometimes the supply is greater than the demand. If allotment labourers are encouraged to become tenant-farmers, their troubles at once begin. Allotments are invaluable, so long as the labourers consume their own prodnce. But in the market they cannot compete with large farmers, except where their proximity to a town affords a ready sale for garden stuff. If all the lands which in these letters have been treated as glebes are to be included in the sale, the larger portion is nusuitable for the purpose from its distance from the village. In this case the Bill must contain a clanse giving the Government the monopoly of laying out allotments, for, in more than one instance, the labourers have thrown up their oldallotments so soon as they obtained more convenient tracts. If, on the other hand, only glebes proper are to be sold, the proposal is grossly unfair to glebeowners. Very often it is only the attraction of the land near the village which enables them to let their remote and scattered parcels. Take away the glebe proper, and the best chance of finding tenants for glebe lands will be gone.

In concluding my letters I beg to express my thanks to the number of clergymen who have kindly rendered me assistance, and whose letters $I$ have in many instances unavoidably left unanswered. I also received valnable aid from many landlords ; also from Mr. Smith Woolley, of South Collingham, Newark; Mr. Castle, of the firm of Messrs. Field and Castle, of Oxford; and Mr. Peter Purves, of Huntingdon. I must also acknowledge my special obligations to the Bishop of Peterborongh and the Ven. Archdeacon of Oakham, without whose advice and assistance I should have been unable to collect any real information respecting the effect of agricultural depression on the iucomes of the clergy. 



$0.690^{\circ}$

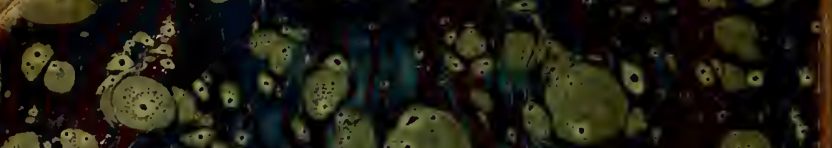
tora

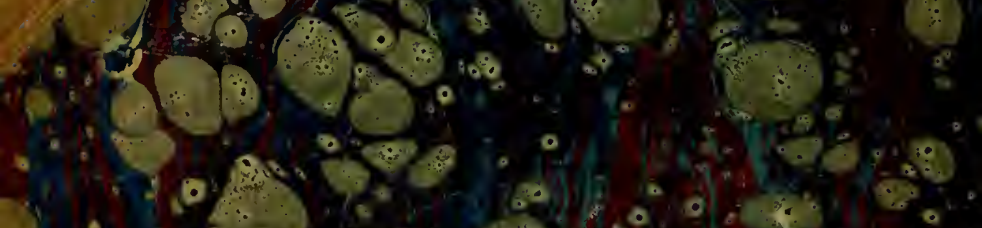
Q0.0.0.0 $\because 5 \%$ O 2010 $\because 20.0 \%$

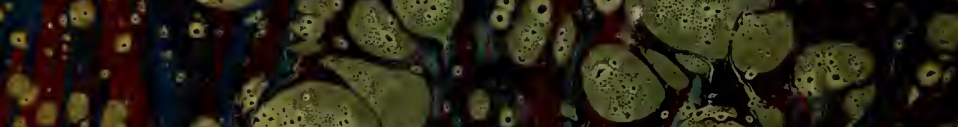

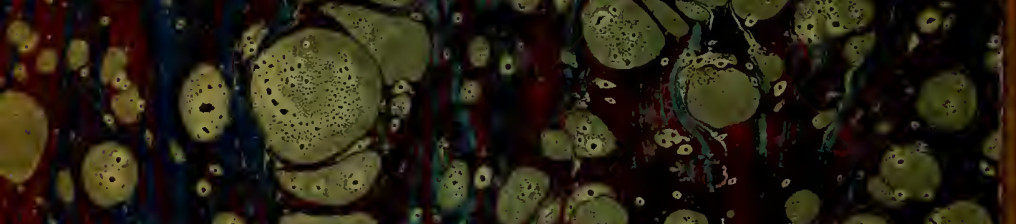
- of 02909

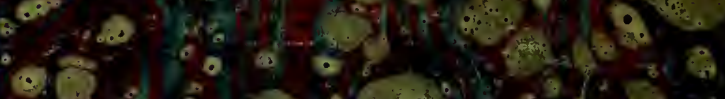
$\therefore$

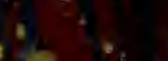 Q. $1 x^{\circ}$

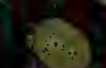
9 .

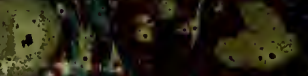

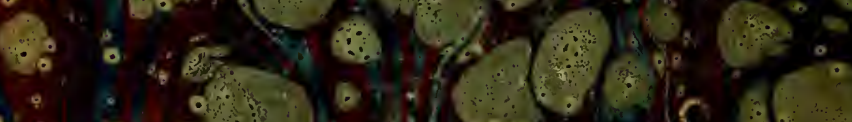

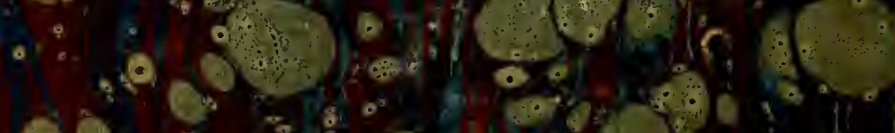

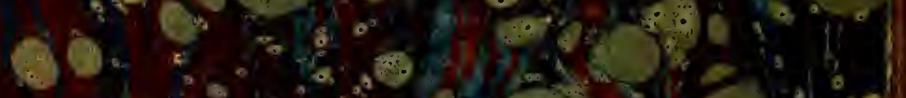

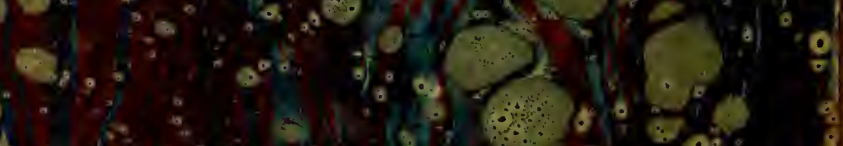

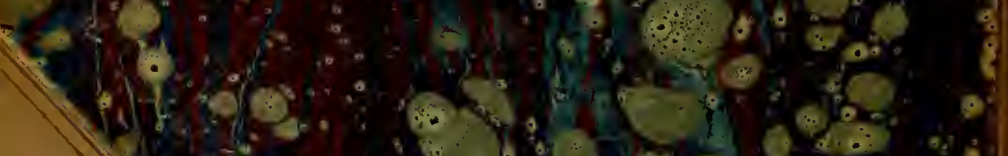

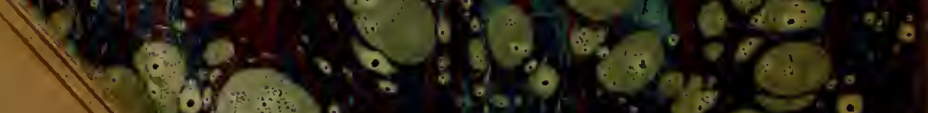

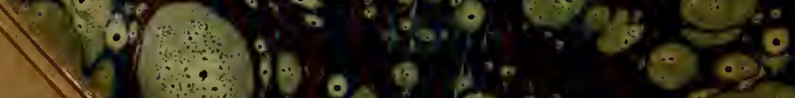

